\title{
Schisandra chinensis Fructus and Its Active Ingredients as Promising Resources for the Treatment of Neurological Diseases
}

\author{
Minyu Zhang ${ }^{1,2}$ (D), Liping $\mathrm{Xu}^{1,2}$ and Hongjun Yang ${ }^{3, *}$ \\ 1 School of Traditional Chinese Medicine, Capital Medical University, Beijing 100069, China; \\ zhangminyu@ccmu.edu.cn (M.Z.); xulp@ccmu.edu.cn (L.X.) \\ 2 Beijing Key Lab of TCM Collateral Disease Theory Research, Capital Medical University, \\ Beijing 100069, China \\ 3 Institute of Chinese Materia Medica, China Academy of Chinese Medical Sciences, Beijing 100700, China \\ * Correspondence: hongjun0420@vip.sina.com; Tel.: +86-10-6401-4411
}

Received: 30 May 2018; Accepted: 30 June 2018; Published: 6 July 2018

\begin{abstract}
Neurological diseases (NDs) are a leading cause of death worldwide and tend to mainly affect people under the age of 50 . High rates of premature death and disability caused by NDs undoubtedly constrain societal development. However, effective therapeutic drugs and methods are very limited. Schisandra chinensis Fructus (SCF) is the dry ripe fruit of Schisandra chinensis (Turcz.) Baill, which has been used in traditional Chinese medicine for thousands of years. Recent research has indicated that SCF and its active ingredients show a protective role in NDs, including cerebrovascular diseases, neurodegenerative diseases, or depression. The key neuroprotective mechanisms of SCF and its active ingredients have been demonstrated to include antioxidation, suppression of apoptosis, anti-inflammation, regulation of neurotransmitters, and modulation of brain-derived neurotrophic factor (BDNF) related pathways. This paper summarizes studies of the role of SCF and its active ingredients in protecting against NDs, and highlights them as promising resources for future treatment. Furthermore, novel insights on the future challenges of SCF and its active ingredients are offered.
\end{abstract}

Keywords: Schisandra chinensis Fructus; active ingredients; neurological diseases; molecular mechanism

\section{Introduction}

Neurological diseases (NDs) are a major public health problem, with high prevalence, and leading to disability and mortality. The World Health Organization estimates that NDs and their sequelae affect as many as one billion people worldwide and are major factors contributing to associated disability and suffering. Cerebrovascular diseases, neurodegenerative diseases, and mental disorders, such as stroke and dementia, rank among the leading causes of death and disability, often affecting the adults in working-age [1]. The health index level of NDs is closely related to the level of regional socioeconomic development. In low- and middle-income countries, the prognosis of NDs is worse, as the resources to treat and manage patients are limited [2]. In China, the prevalence of cerebrovascular diseases has increased to $12.3 \%$ in rural areas, as evidenced by a survey taken every five years, from 1993 to 2013 [3]. The current number of cardiovascular and cerebrovascular diseases patients is 290 million, including 13 million stroke patients.

The treatment of NDs, including stroke and Alzheimer's disease (AD), is critical to patients' lifespan and quality of life. However, effective therapeutic drugs and methods are very limited. Even in high-income countries, stroke remains a common cause of death and disability [4], and women 
experience more stroke over their lifetime and more deaths from stroke $[5,6]$, compared with men. The management of patients who suffer from acute ischemic stroke at an early stage is crucial and existing drugs are limited [7]. In addition, $\mathrm{AD}$ is a progressive neurodegenerative phenotype with complex cerebrovascular disorders [8]. The current treatment of AD mainly consists of neuroleptics, antidepressants, and benzodiazepines. However, drug interactions and toxicity resulting from the long-time use of pleiotropic drugs exacerbate the clinical symptoms of patients [9]. Therefore, it is necessary to find effective drugs to treat these NDs.

Schisandra chinensis Fructus (SCF) is the dry ripe fruit of Schisandra chinensis (Turcz.) Baill, which tastes sweet and sour. In traditional Chinese medicine it is mainly used for the treatment of dysphoria and palpitation, insomnia, and many dreams resulting from the poor preservation of the patient's spirit [10,11]. The main components of SCF include lignans, volatile oils, and polysaccharides [12,13]. Previous studies have revealed the properties of SCF and its active components, including anti-myocardial dysfunction [14], anti-myocardial ischemia/reperfusion (I/R) injury [15], hepatoprotective effects [16], anti-tumor effects [17], and anti-HIV effects [18]. More recent advances have demonstrated that SCF and its active ingredients, schizandrin $\mathrm{A}$ (Sch A), schizandrin $\mathrm{B}$ (Sch B), schizandrin C (Sch C), schisantherin A (STA), schisandrin (SCH), schizandrol B, $\alpha$-isocubebenol (ICO), gomisin A, gomisin N, and nigranoic acid, manifest protective effects on hypoxia-ischemia neural injury and neurodegenerative diseases, including stroke, AD, and Parkinson's disease (PD). This paper summarizes the neuroprotective effects of SCF and its active ingredients, and provides a reference for the treatment of NDs.

\section{Literature and Data Search Methodology}

Pathway and biological term enrichment was based on the Bioinformatics Analysis Tool for Molecular mechANism of Traditional Chinese Medicine (BATMAN-TCM) [19]. The literature search was based on electronic databases, including PubMed/MEDLINE, CNKI, ScienceDirect, and Scopus, from 2000 to 2018. Search terms included SCF, SCF ingredients, SCF lignans, NDs, cerebrovascular diseases, neurodegenerative diseases, neuron, brain, oxidative stress, apoptosis, inflammation, neurotransmitters disorders, stroke, $\mathrm{AD}, \mathrm{PD}$, depression, and anxiety.

\section{Biological Function Enrichment of SCF}

The results from searching in the BATMAN database showed that the biological mechanisms of SCF are mostly linked to neurologically related functions (Figure 1). Of the top 15 biological terms, 11 are strongly linked to mental functions, namely, neuroactive ligand-receptor interaction, the calcium signaling pathway, the cGMP-dependent protein kinase (cGMP-PKG) signaling pathway, dopaminergic synapse, serotonergic synapse, the adenosine monophosphate activated protein Kinase (AMPK) signaling pathway, retrograde end cannabinoid signaling, gap junctions, cholinergic synapses, the peroxisome proliferators activated receptor (PPAR) signaling pathway, and inflammatory mediator regulation of transient receptor potential (TRP) channels. The results indicated that SCF and its bioactive ingredients could potentially be treatments for NDs.

A literature search was carried out, focusing on the protective effect of SCF and its active components on NDs. The results showed that their main mechanisms are antioxidation, suppression of apoptosis, anti-inflammation, regulation of neurotransmitters, and modulation of pathways related to brain-derived neurotrophic factor (BDNF) (Table 1). 
Table 1. Summary of the pharmacological effects and biological analysis of Schisandra chinensis Fructus (SCF) and its active ingredients. BDNF-brain-derived neurotrophic factor; CREB-cAMP-response element binding protein; PI3K-phosphatidylinositol 3-kinase; GSK—glycogen synthase kinase; TLS—-total lignans of SCF; SCH—schisandrin; ICO— $\alpha$-isocubebenol; STA—schisantherin A; GSH—glutathione; NO—nitric oxide; ERK—extracellular signal-regulated kinase; NE-norepinephrine; MAPK—-mitogen-activated protein kinases; TRAF6-tumor necrosis factor-associated factor 6; IKK-inhibitory kappa B kinase; NF- $\mathrm{B}$-nuclear translocation of nuclear factor- $\mathrm{kB}$; Jak2/Stat3-Janus kinase-2/signal transducer and activator of transcription-3; GLT-1-glutamate transporter type 1; NADPH-nicotinamide adenine dinucleotide phosphate; JNK-c-Jun NH2-terminal kinases; RAGE-receptors for advanced glycation end products; ROS-reactive oxygen species.

\begin{tabular}{|c|c|c|c|}
\hline $\begin{array}{c}\text { SCF and Its } \\
\text { Active Ingredients }\end{array}$ & Pharmacological Activity & Biological Analysis & Key References \\
\hline \multirow{4}{*}{ SCF } & Anti-oxidant & GSH antioxidant response & {$[20,21]$} \\
\hline & Modulate BDNF related pathways & $\begin{array}{l}\text { BDNF, TrkB/CREB/ERK and } \\
\text { PI3K/Akt/GSK-3 } \beta \text { pathways }\end{array}$ & {$[22,23]$} \\
\hline & Regulate neurotransmitters & NE activity & [24] \\
\hline & & Neurotransmitters activities & [25] \\
\hline \multirow{6}{*}{ TLS } & Anti-oxidant & Mitochondrial function & [26] \\
\hline & & GSH antioxidant response & [27] \\
\hline & Anti-apoptosis & Bcl-2 expression & [26] \\
\hline & & Bcl-2 and Bax expression & [28] \\
\hline & Anti-inflammatory & NO activity & [29] \\
\hline & & MAPKs signaling & [26] \\
\hline \multirow{3}{*}{ Sch A } & Anti-oxidant & GSH antioxidant response & [30] \\
\hline & Anti-apoptosis & ERK, JNK, Caspase-3 signaling & [31] \\
\hline & Anti-inflammatory & $\begin{array}{l}\text { TRAF6/IKK } \beta / N F-\kappa B \text { and Jak2/Stat3 } \\
\text { signaling pathways }\end{array}$ & [32] \\
\hline \multirow{9}{*}{ Sch B } & Anti-oxidant & ACh activity & [33] \\
\hline & & GSH antioxidant response & [34] \\
\hline & & GLT- 1 and GSK3 $\beta$ activities & [35] \\
\hline & & ROS, NADPH oxidase activity & [36] \\
\hline & Anti-apoptosis & Caspase-3, HSP70, beclin-1 expression & [37] \\
\hline & Anti-inflammatory & RAGE, NF- $\kappa \mathrm{B}, \mathrm{MAPKs}$ signaling & [37] \\
\hline & & PPAR- $\gamma$ activity & [38] \\
\hline & & MyD88/IKK/NF- $k B$ signaling pathway & [36] \\
\hline & & TNF- $\alpha$, IL- $1 \beta$ activities & [39] \\
\hline \multirow{2}{*}{ Sch C } & Anti-apoptosis & JNK/Caspase-3 signaling & [40] \\
\hline & Anti-inflammatory & cAMP/PKA/CREB and Nrf-2 signaling & [41] \\
\hline \multirow{4}{*}{ STA } & Anti-oxidant & MAPKs, PI3K/Akt and GSK $3 \beta$ signaling & [42] \\
\hline & & GSH antioxidant response & [43] \\
\hline & Anti-apoptosis & $\mathrm{Bcl}-2$ expression and PI3K/Akt signaling & [44] \\
\hline & & JNK/Caspase-3 signaling & [40] \\
\hline \multirow{2}{*}{$\mathrm{SCH}$} & Anti-oxidant & GSH antioxidant response & [45] \\
\hline & Regulate neurotransmitters & Neurotransmitters and their metabolites effects & [46] \\
\hline Schizandrol B & Anti-apoptosis & JNK/Caspase-3 signaling & [40] \\
\hline \multirow{4}{*}{$\mathrm{ICO}$} & Anti-oxidant & ROS and calcium accumulation & [47] \\
\hline & Anti-apoptosis & CREB/Nrf-2 signaling & [47] \\
\hline & & Bcl-2 and Bax expression & [48] \\
\hline & Anti-inflammatory & NF- $\kappa B$ and MAPK signaling pathways & [49] \\
\hline \multirow{3}{*}{ Gomisin A } & Anti-oxidant & ROS, NADPH oxidase activity & [50] \\
\hline & Anti-apoptosis & CYP3A activity & [51] \\
\hline & Anti-inflammatory & TLR4 mediated NF- $\kappa B$ and MAPKs pathways & [50] \\
\hline Gomisin N & Anti-inflammatory & Inflammatory responses and neural activation & [52] \\
\hline Nigranoic acid & Modulate BDNF related pathways & ERK1/2, $\mathrm{Ca}^{2+}$-CaMKII pathways, BDNF activity & [53] \\
\hline
\end{tabular}




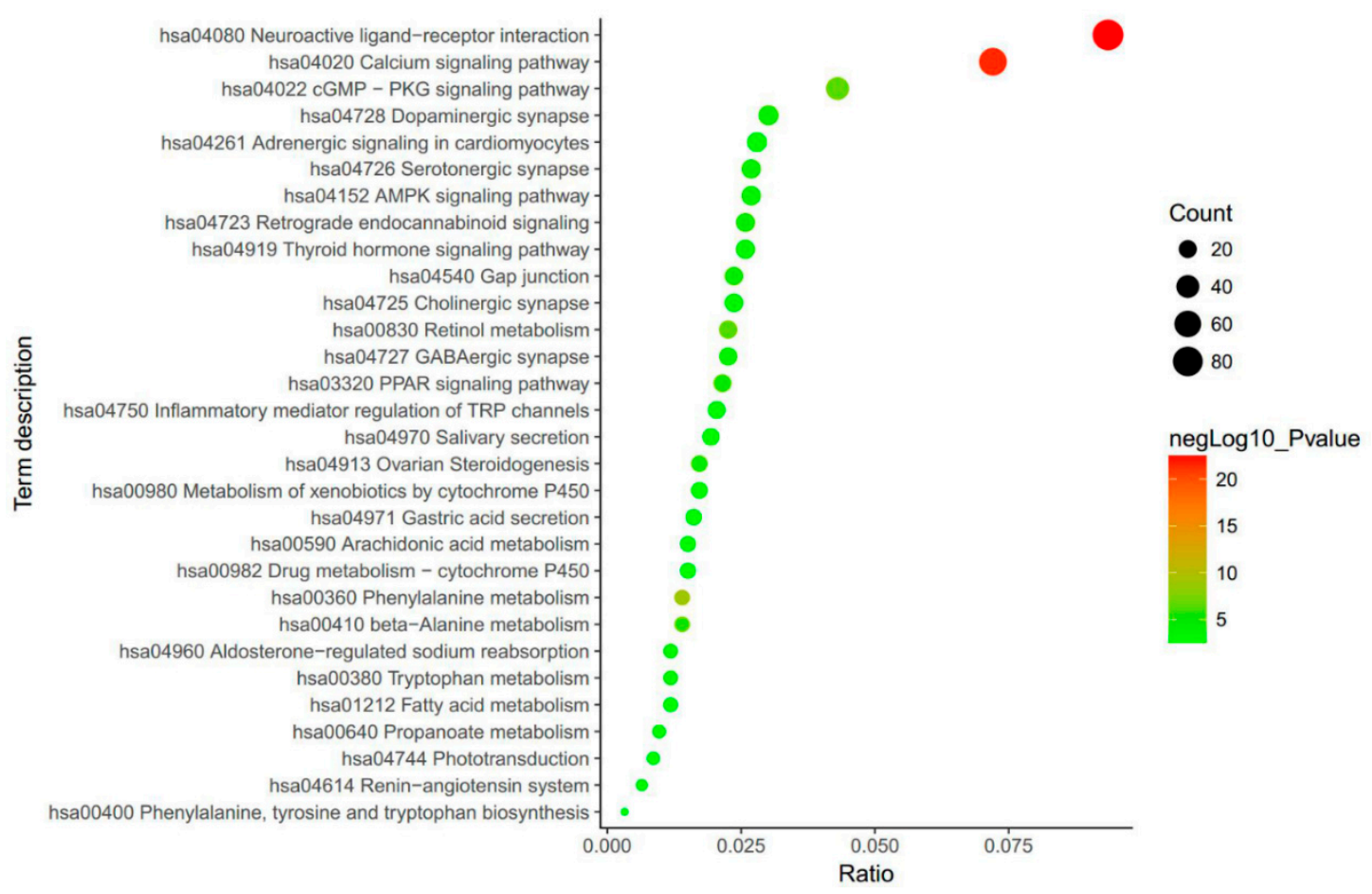

Figure 1. The biological mechanisms enrichment of Schisandra chinensis Fructus (SCF). The round represents the relationship between SCF and the biological terms. The size of the round signifies the count of the signaling pathways or functions. The color denotes the $\log 10$ of $p$ value. The closer to red, the smaller $p$ value is.

\section{Antioxidative Effect in Neurological Diseases}

Oxidative stress is one of the main causes of neural injury and neurodegeneration [54]. Moreover, because of the fact that antioxidant substances cannot easily penetrate the blood-brain barrier, brain tissue is particularly sensitive to oxidative stress [55]. The oxidizable/reducible chemical pairs, including reduced thioredoxin/oxidized thioredoxin, glutathione/glutathione disulfide, and $\mathrm{NAD}^{+} / \mathrm{NADH}$ (and NADP/NADPH), determine the overall redox potential of a cell [56].

Increasing evidence demonstrates that oxidative stress participates in the pathophysiological processes of stroke (including ischemia-reperfusion injury) and other brain injuries $[57,58]$. The production of reactive oxygen species (ROS) rapidly increases and overwhelms the antioxidant defenses. An excess of ROS directly modifies or degenerates cellular macromolecules, causing lipid peroxidation, protein oxidation, and DNA damage in neural tissues, and finally leading to brain injury $[59,60]$. In neurodegenerative diseases, the increased ROS leads to neuronal dysfunction. In the early events of $\mathrm{AD}$, ROS are related to $\mathrm{A} \beta$-induced nerve injury, as well as the abnormal phosphorylation of tau proteins. In addition, the accumulated ROS exacerbate dopaminergic neuronal death in the substantia nigra of PD patients [61]. In neuronal excitotoxicity, stroke, and neurodegenerative disease, increased extracellular glutamate levels bring about calcium overload, as well as mitochondrial dysfunction [62]. Therefore, redox regulation has recently been recognized as an important factor in acute and chronic NDs [63]. SCF and its ingredients were shown to manifest neuroprotective effects on NDs by attenuating oxidative stress (Figure 2). The pharmacological data are shown in Table 2. 
Table 2. The pharmacological data of SCF and its active ingredients in protecting against NDs by anti-oxidative effect. LPS-lipopolysaccharide; 6-OHDA-6-hydroxydopamine; CTX-cyclophosphamide; AD-Alzheimer's disease; NS—neurological disease; MDA-malondialdehyde; I/R—ischemia/reperfusion; T-AOC—-total antioxidant capacity; GSSG—glutathione disulfide; CAT—catalase.

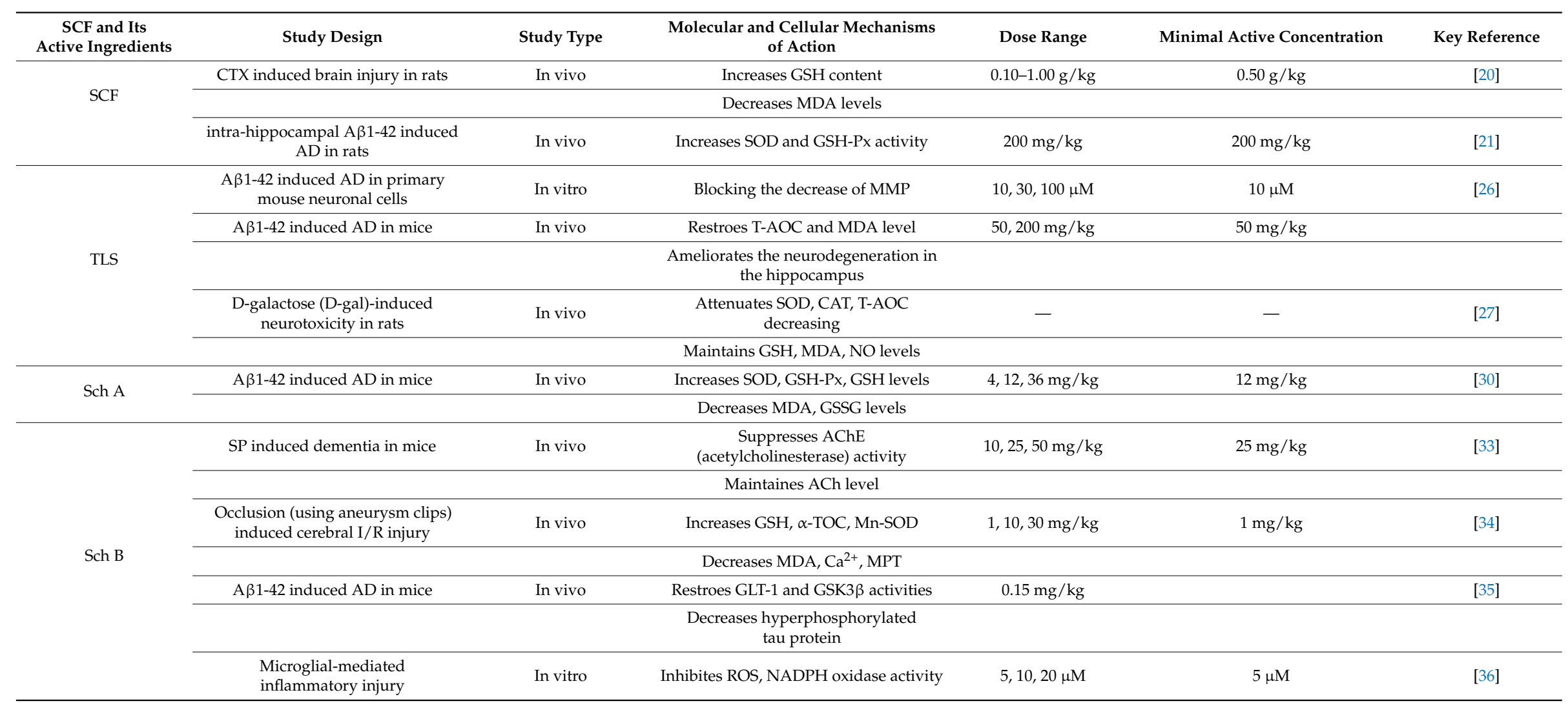


Table 2. Cont

\begin{tabular}{|c|c|c|c|c|c|c|}
\hline $\begin{array}{c}\text { SCF and Its } \\
\text { Active Ingredients }\end{array}$ & Study Design & Study Type & $\begin{array}{l}\text { Molecular and Cellular Mechanisms } \\
\text { of Action }\end{array}$ & Dose Range & Minimal Active Concentration & Key Reference \\
\hline \multirow{8}{*}{ STA } & $\begin{array}{l}\text { 6-OHDA-induced neural damage in } \\
\text { SH-SY5Y cells }\end{array}$ & In vitro & Decreases cytotoxicity & $3,6,12,25,50,100 \mu \mathrm{M}$ & $14.8 \mu \mathrm{M}(\mathrm{EC} 50)$ & [42] \\
\hline & \multicolumn{5}{|c|}{ Down-regulates ROS level } & \\
\hline & \multicolumn{5}{|c|}{ Inhibites NO, iNOS levels } & \\
\hline & \multicolumn{5}{|c|}{$\begin{array}{c}\text { Opposes ERK } \\
\text { phosphorylation decreases }\end{array}$} & \\
\hline & \multicolumn{5}{|c|}{ Up-ragulates p-Akt/t-Akt ratio } & \\
\hline & \multicolumn{5}{|c|}{ Preventes GSK3 $\beta$ dephosphorylation } & \\
\hline & $\begin{array}{l}\text { 6-OHDA-induced neural damage in } \\
\text { zebrafish }\end{array}$ & In vivo & Prevents dopaminergic neuron loss & $2.5,5,10 \mu \mathrm{M}$ & $10 \mu \mathrm{M}$ & \\
\hline & $A \beta 1-42$ induced $A D$ in mice & In vivo & $\begin{array}{c}\text { Restroes SOD, GSH-Px, MDA, } \\
\text { GSH activites }\end{array}$ & $0.01-0.1 \mathrm{mg} / \mathrm{kg}$ & $0.1 \mathrm{mg} / \mathrm{kg}$ & [43] \\
\hline \multirow{2}{*}{$\mathrm{SCH}$} & $\mathrm{A} \beta 1-42$ induced $\mathrm{AD}$ in mice & In vivo & Increases SOD, GSH-Px, GSH levels & $4,12,36 \mathrm{mg} / \mathrm{kg}$ & $36 \mathrm{mg} / \mathrm{kg}$ & [45] \\
\hline & \multicolumn{5}{|c|}{ Decreases MDA, GSSG levels } & \\
\hline \multirow{3}{*}{ ICO } & $\begin{array}{l}\text { 6-OHDA-induced neural damage in } \\
\text { SH-SY5Y cells }\end{array}$ & In vitro & Inhibites ROS & $20,40,80 \mu \mathrm{M}$ & $40 \mu \mathrm{M}$ & [47] \\
\hline & \multicolumn{5}{|c|}{ Inhibites calcuim accumulation } & \\
\hline & \multicolumn{5}{|c|}{ Increases NQO1, HO-1 levels } & \\
\hline Gomisin A & LPS-stimulated N9 microglia & In vitro & $\begin{array}{l}\text { Inhibites ROS, NADPH, } \\
\text { gp91phox expression }\end{array}$ & $1-100 \mu \mathrm{M}$ & $3 \mu \mathrm{M}$ & [50] \\
\hline
\end{tabular}




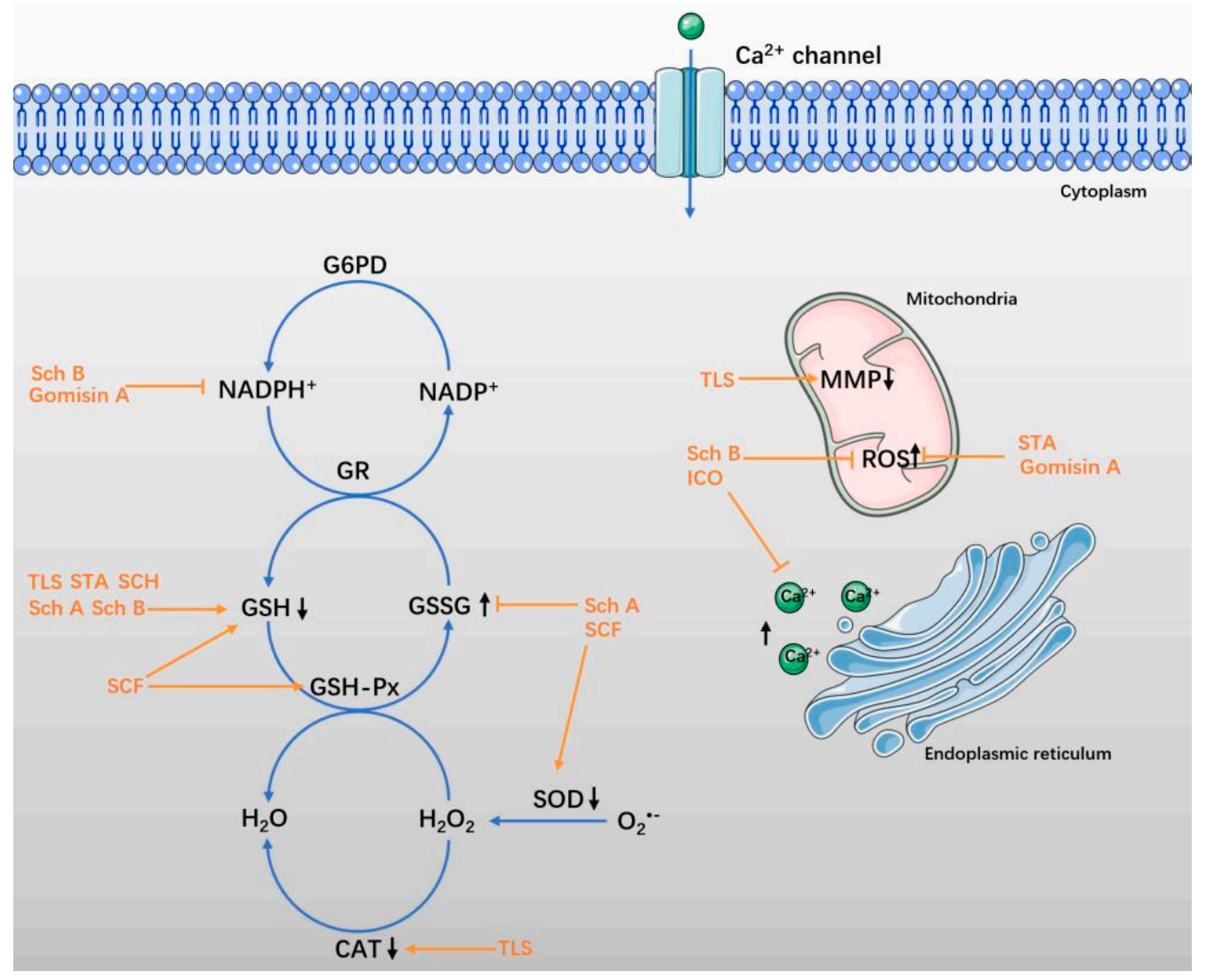

Figure 2. SCF and its active ingredients protect against oxidative stress in neurological diseases (NDs). Under pathological conditions, the redox balance is disrupted. The degradation of glutathione (GSH) is accelerated when the GSH-Px activity is decreased, and the production of glutathione disulfide (GSSG) is increased [64-66]. The expression of enzymes with antioxidant effects, as superoxide dismutase (SOD) and catalase (CAT), are inhibited simultaneously [67-69]. The mitochondrial membrane potential (MMP) decreases, while reactive oxygen species (ROS) is released excessively [70,71]. Intracellular $\mathrm{Ca}^{2+}$ influx, as well as intracellular $\mathrm{Ca}^{2+}$ release from the endoplasmic reticulum are increased, resulting in a series of downstream pathological responses [72-74]. The protective effect of SCF and its active ingredients are shown in orange.

\subsection{SCF and Total Lignans of SCF}

SCF was supposed to be a complementary medicine in cyclophosphamide (CTX) treatment for its effect of reducing chloroacetaldehyde (CAA) production and decreasing the $\mathrm{C}_{\max }$ and AUC0-24h of 2-dechloroethylcyclophosphamide (DCCTX). With SCF treatment, brain glutathione (GSH) content increased and malondialdehyde (MDA) levels were reduced in rats with CTX-induced damage [20]. Yang et al. reported that SCF showed an antioxidant effect on AD rats by elevating superoxide dismutase (SOD) and glutathione peroxidase (GSH-Px) activity, and reducing MDA level [21].

The lignans extracted from SCF were identified as a potential treatment for AD, because of their protection against damage from oxidative stress. In a recent report, the total lignans of SCF (TLS) blocked the decrease of mitochondrial membrane potential (MMP) in primary mouse neuronal cells. Moreover, TLS restored the activity of total antioxidant capacity (T-AOC) in AD mice (see Sections 5.1 and 6.1 for more detail) [26]. In addition, the lignans of SCF were assumed to protect against D-galactose (D-gal)-induced neurotoxicity in rats by maintaining GSH, MDA, and nitric oxide (NO) levels, and alleviating the decrease of SOD, catalase (CAT), and T-AOC activity. They were demonstrated to be potential candidates for the treatment of aging-associated neurodegenerative diseases [27]. 


\subsection{Sch $A$ and Sch B}

Sch A and Sch B, derived from SCF, manifested anti-oxidative effects on AD. In research by $\mathrm{Hu}$ et al. Sch A significantly attenuated short-term and spatial memory impairments in AD mice by upregulating SOD, MDA, GSH-Px, GSH levels, and glutathione disulfide (GSSG) levels [30]. Furthermore, Sch B attenuated learning and memory impairment of AD mice induced by A $\beta 1-42$. The restoration of glutamate transporter type 1 (GLT-1) and the capacity of glycogen synthase kinase $3 \beta$ (GSK3 $\beta$ ) were maintained by Sch B treatment [35].

In a study by Chen et al. Sch B showed a protective effect in rats with cerebral ischemia/reperfusion (I/R) injury by strengthening the cerebral mitochondrial antioxidant effect. With the Sch B treatment, the GSH, $\alpha$-TOC, and Mn-SOD expressions were increased, whereas the MDA-level and $\mathrm{Ca}^{2+}$-induced permeability transition was decreased [34]. In addition, Sch B relieved microglial-mediated inflammatory injury by inhibiting ROS and NADPH oxidase activity (see Section 6.2 for more detail) [36]. Sch B also modulated acetylcholine (ACh) activity in mice with dementia induced by scopolamine. The ACh level was maintained as normal, while the acetylcholinesterase (AChE) activity was inhibited by Sch B [33].

\subsection{STA and SCH}

STA is regarded as a neuroprotective lignin and works by attenuating the damage induced by 6-hydroxydopamine (6-OHDA) during in vivo and in vitro experiments. It alleviated neural damage by inhibiting ROS and NOS overproduction, and regulating extracellular signal-regulated kinase (ERK) phosphorylation, phosphatidylinositol 3-kinase (PI3K)/ Akt ratio, and GSK3 $\beta$ dephosphorylation [42]. Moreover, STA restored SOD, GSH-Px, MDA, and GSH activity in AD mice, which indicated its protective effect against cognitive deficits and oxidative stress [43].

SCH is a bioactive lignan isolated from SCF. It has been suggested as a potential cognitive enhancer against $\mathrm{AD}$ through an antioxidative effect. As $\mathrm{Hu}$ et al. reported, $\mathrm{SCH}$ improved short-term and spatial memory impairments by upregulating SOD, GSH-Px, and GSH activity, and downregulating MDA and GSSG levels in the cerebral cortex and hippocampus of AD mice [45].

\subsection{ICO and Gomisin A}

ICO isolated from SCF showed an antioxidative effect on 6-OHDA-induced human neuroblastoma SH-SY5Y cell (a human derived cell line used as in vitro models of neuronal function and differentiation) death, inhibiting ROS and calcium accumulation. Additionally, ICO stimulated the expression of the antioxidant response genes NQO1 and HO-1 (see Section 5.4 for more detail) [47]. Moreover, gomisin A inhibited the ROS production, NADPH oxidase activation, and gp91phox expression induced by lipopolysaccharide (LPS) in microglia (see Section 6.3 for more detail) [50].

\section{Suppression of Apoptosis}

Apoptosis is the main mechanism behind the appearance of DNA in circulation [75]. On the one hand, apoptosis may contribute to a significant proportion of neuronal death following acute brain ischemia (ABI), which may lead to stroke [76]. On the other hand, when ischemic stroke and neurodegenerative diseases such as AD and PD occur, the apoptosis results in profound brain injury, including neuronal death and loss of neurological functions [77-79]. More recent advances have revealed that the cell death pathways of apoptosis, intracellular $\mathrm{Ca}^{2+}$ homeostasis, and key metabolic pathways are regulated by mitochondria in neurologic disease [80]. More specifically, with more suppressed mitochondrial respiration comes more dysregulated calcium signaling. Furthermore, caspase-dependent and apoptosis-inducing factor-dependent apoptotic cell deaths are activated by Bax-dependent mitochondrial permeabilization [81,82]. SCF and its ingredients protect against NDs by suppressing apoptosis (Figure 3). The pharmacological data are shown in Table 3. 


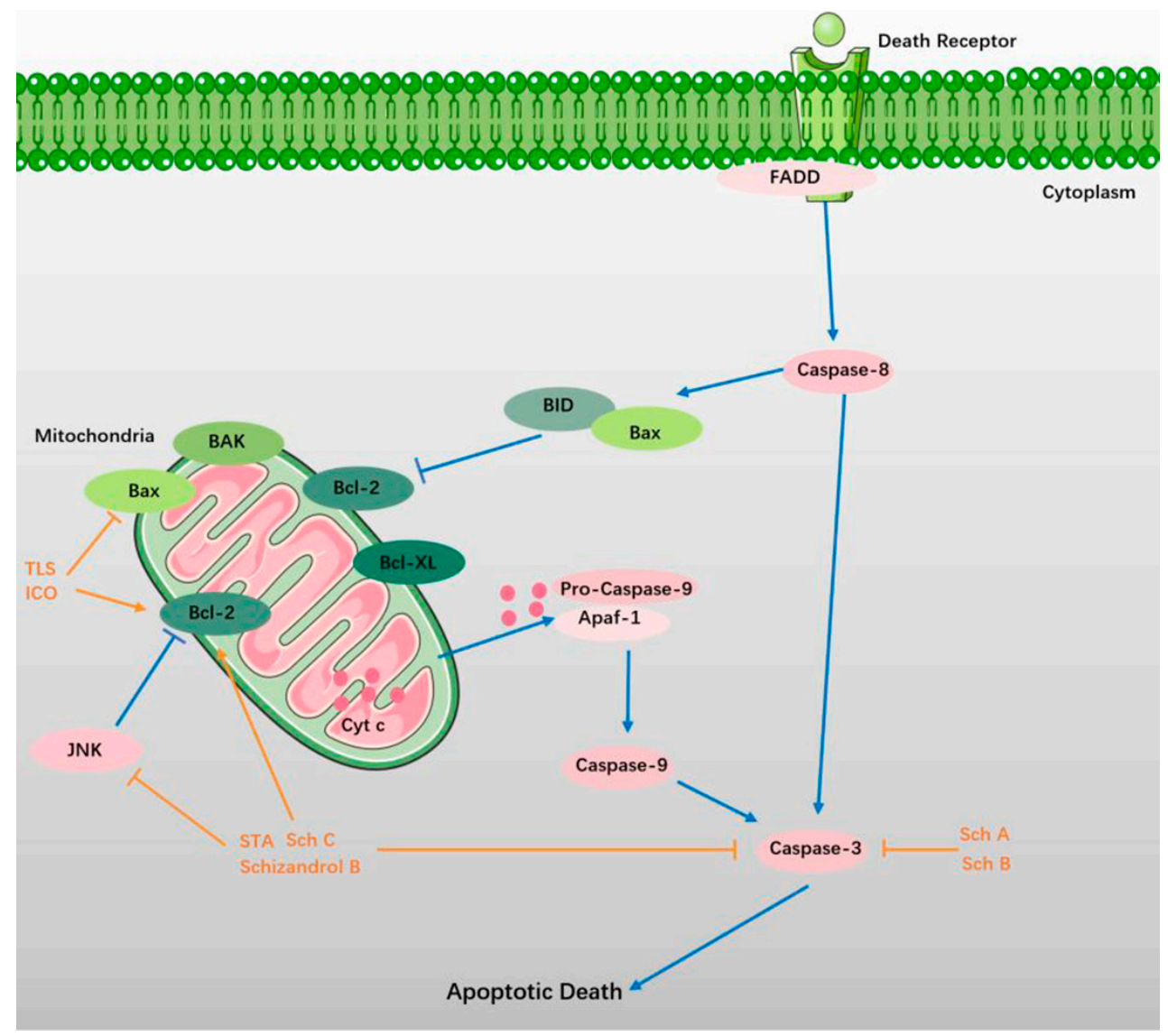

Figure 3. SCF and its ingredients attenuate apoptosis in NDs. Apoptosis are initiated by various external factors through the signal transduction of apoptosis signal with membrane receptors $[83,84]$. The apoptosis-inducing complex on the cell membrane includes a Fas-assiociated protein with death domain protein (FADD), of which N-terminal (DED) homophilic crosslinks with the inactive caspase-8. With the activating of caspase-8, the following cascade reactions are promoted [85-87]. Bax migrates from the cytosol to the mitochondria in apoptosis [88,89]. Mitochondrial Bcl-2 exerts an anti-apoptotic effect by preventing the release of mitochondrial cytochrome c (Cyt c), and reducing the activity of caspase [90-92]. Cyt c released into the cytoplasm binds to apoptosis-related factor 1 (Apaf-1) in the presence of dATP, and forms apoptotic bodies with caspase-9. With the activating of caspase-9, caspase- 3 is subsequently activated to induce apoptosis [93-95]. The protective effect of SCF and its active ingredients are shown in orange.

\subsection{TLS}

In a study by Jiang et al. TLS manifested a protective effect on rats with cerebral ischemia injury. The mechanism is related to increased Bcl-2 and p-Akt levels and the inhibition of apoptin Bax expression in the cerebral infarction area [28]. Moreover, TLS showed significant antiapoptotic effects in A $31-42$-induced $\mathrm{AD}$ in primary mouse neuronal cells, by increasing Bcl-2 expression [26].

\subsection{Sch $A$ and Sch $B$}

Sch A has been reported to reduce cell apoptosis and necrosis in primary cultures of rat cortical neurons after oxygen and glucose deprivation, followed by reperfusion (OGD/R). Intracellular $\mathrm{Ca}^{2+}$ and LDH levels were decreased by Sch A treatment. Proteins play an important role in neuronal apoptosis, c-Jun NH2-terminal kinases (JNK), p38, and caspase-3 were modulated by Sch A in H293T cells [31]. Furthermore, Sch B showed antiapoptotic and anti-autophagy effects in rats with AD induced by $A \beta(1-40)$. In these experiments, the overexpression of caspase- 3 and terminal transferase-mediated 
dUTP nick-end labeling (TUNEL) positive cells were suppressed by Sch B treatment. In addition, proteins such as HSP70 and beclin-1 were upregulated by Sch B (see Section 6.2 for more detail) [37].

\subsection{STA, Sch C, and Schizandrol B}

As Sa et al. reported, STA pretreatment inhibited 1-methyl-4-phenylpyridinium ion $\left(\mathrm{MPP}^{+}\right)$-induced cytotoxicity in SH-SY5Y cells and 1-methyl-4-phenyl-1,2,3,6-tetrahydropyridine (MPTP)-induced the loss of TH-positive dopaminergic neurons in PD mice. The mechanism was suggested to increase cAMP-response element binding protein (CREB)-mediated Bcl-2 expression and activate PI3K/Akt signaling [44]. In addition, STA, Sch C, and Schizandrol B showed beneficial effects in preventing serum and glucose deprivation (SGD) injury. Overexpressed proteins related to apoptosis were regulated by these lignans [40].

\subsection{ICO and Gomisin A}

$\alpha$-Isocubebenol (ICO) derived from SCF was recently shown to exert neuroprotective properties with an antiapoptotic effect. In the scopolamine-induced AD mice, ICO significantly upregulated the Bcl-2/Bax ratio. In addition, the AChE activity and decreased ERK phosphorylation induced by scopolamine were attenuated by ICO treatment [48]. In an in vitro experiment, ICO showed a protective effect on 6-OHDA-induced neural damage in SH-SY5Y cells. The mechanism was suggested to inhibit the release of the apoptosis-inducing factor from the mitochondria into the cytosol and nucleus [47]. In addition, gomisin A protected against CTX toxicity by blocking CYP3A-mediated metabolism and reducing CAA production in GH3 cells [51]. 
Table 3. The pharmacological data of SCF and its active ingredients in protecting against NDs by suppressing apoptosis. TUNEL-terminal transferase-mediated dUTP nick-end labeling; OGD/R- oxygen and glucose deprivation followed by reperfusion.

\begin{tabular}{|c|c|c|c|c|c|c|}
\hline $\begin{array}{c}\text { SCF and Its } \\
\text { Active Ingredients }\end{array}$ & Study Design & Study Type & Molecular and Cellular Mechanisms of Action & Dose Range & Minimal Active Concentration & Key Reference \\
\hline \multirow[t]{2}{*}{ TLS } & $\begin{array}{l}\mathrm{A} \beta 1-42 \text { induced } \mathrm{AD} \text { in primary mouse } \\
\text { neuronal cells }\end{array}$ & In vitro & Increase Bcl-2 expressions & $10,30,100 \mu \mathrm{M}$ & $10 \mu \mathrm{M}$ & [26] \\
\hline & $\begin{array}{l}\text { Suture-occluded induced cerebral } \\
\text { ischemia injury }\end{array}$ & In vivo & Inhibites Bax level & $25-100 \mathrm{mg} / \mathrm{kg}$ & $25 \mathrm{mg} / \mathrm{kg}$ & [28] \\
\hline \multicolumn{7}{|c|}{ Increases Bcl-2, p-Akt levles } \\
\hline Sch A & $\begin{array}{l}\text { OGD/R-induced cell death in primary } \\
\text { culture of rat cortical neurons }\end{array}$ & In vitro & Decreases $\mathrm{Ca}^{2+}, \mathrm{LDH}$ levels & $1.25,2.5,5 \mu \mathrm{g} / \mathrm{mL}$ & $1.25 \mu \mathrm{g} / \mathrm{mL}$ & [31] \\
\hline \multicolumn{7}{|c|}{ Up-regulates C3aR, C5aR levels } \\
\hline & H293T cell & & Down-regulates ERK, JNK, p38, caspase-3 levels & & & \\
\hline \multicolumn{7}{|c|}{ Up-regulates HSP70, beclin-1 } \\
\hline Sch C, Schizandrol B & $\begin{array}{l}\text { Serum and glucose deprivation (SGD) } \\
\text { injury in SH-SY5Y cells }\end{array}$ & In vitro & Inhibites LDH level & $2.5,5.0 \mathrm{mg} / \mathrm{mL}$ & $2.5 \mathrm{mg} / \mathrm{mL}$ & [40] \\
\hline \multicolumn{7}{|c|}{$\begin{array}{c}\text { Inhibites NLRP3, Caspase-1, IL-1 } \beta, \text { NF-kB, plkB/1kB, } \\
\text { pJNK1/2, JNK1/2, Caspase-3 expression }\end{array}$} \\
\hline STA & $\begin{array}{l}\mathrm{MPP}^{+} \text {induced neural damage in } \\
\text { SH-SY5Y cells }\end{array}$ & In vitro & Decreases cytotoxicity & $60 \mu \mathrm{M}$ & $60 \mu \mathrm{M}$ & [44] \\
\hline \multicolumn{7}{|c|}{ Increases CREB, Bcl-2 expression } \\
\hline \multicolumn{7}{|c|}{ Activates PI3K and Akt levels } \\
\hline & $\begin{array}{l}\text { Serum and glucose deprivation (SGD) } \\
\text { injury in SH-SY5Y cells }\end{array}$ & In vitro & Inhibites LDH level & $2.5,5.0 \mathrm{mg} / \mathrm{mL}$ & $2.5 \mathrm{mg} / \mathrm{mL}$ & [40] \\
\hline \multicolumn{7}{|c|}{$\begin{array}{c}\text { Inhibites NLRP3, Caspase-1, IL-1 } \beta \text {, NF-kB, plkB/1kB, } \\
\text { pJNK1/2, JNK1/2, Caspase-3 expression }\end{array}$} \\
\hline ICO & $\begin{array}{l}\text { 6-OHDA-induced neural damage in } \\
\text { SH-SY5Y cells }\end{array}$ & In vitro & Inhibites TUNEL positive cells & $20,40,80 \mu \mathrm{M}$ & $40 \mu \mathrm{M}$ & [47] \\
\hline \multicolumn{7}{|c|}{ Inhibites the release of AIF } \\
\hline \multicolumn{7}{|c|}{ Stimulates the activation of PKA/PKB/CREB/Nrf-2 } \\
\hline & $\begin{array}{l}\text { SP induced memory impairment in } \\
\text { mice }(\mathrm{AD})\end{array}$ & In vivo & Decreases AChE activity & $5,10 \mathrm{mg} / \mathrm{kg}$ & $5 \mathrm{mg} / \mathrm{kg}$ & [48] \\
\hline \multicolumn{7}{|c|}{ Up-ragulates Bcl-2/Bax ratio } \\
\hline \multicolumn{7}{|c|}{ Attenuates the decrease of ERK phosphorylation } \\
\hline Gomisin A & CTX induced brain injury in rats & In vivo & Blocking CYP3A-mediated metabolism & $20.8 \mathrm{mg} / \mathrm{kg}$ & $20.8 \mathrm{mg} / \mathrm{kg}$ & [51] \\
\hline & & & Reducing CAA production & & & \\
\hline
\end{tabular}




\section{Anti-Inflammatory Effect}

Neuroinflammation has been proven to contribute to the etiology of hypoxia-ischemia neural injury and neurodegenerative diseases [96]. Despite discrepancies in their pathophysiological timeframe and severity, NDs share common molecular mechanisms that include inflammation, mitochondrial dysfunction, and endoplasmic reticulum stress [79]. In an ischemic stroke, neuroinflammatory processes are upregulated and initiate a feedback loop of inflammatory cascades that can expand the region of damage [97]. Inflammatory molecules such as cytokines, chemokines, and reactive oxygen and nitrogen species are thought to be pivotal mediators of persistent neuronal injury [98-100]. SCF and its ingredients exert a neuroprotective effect on NDs by alleviating inflammation (Figure 4). The pharmacological data are shown in Table 4.

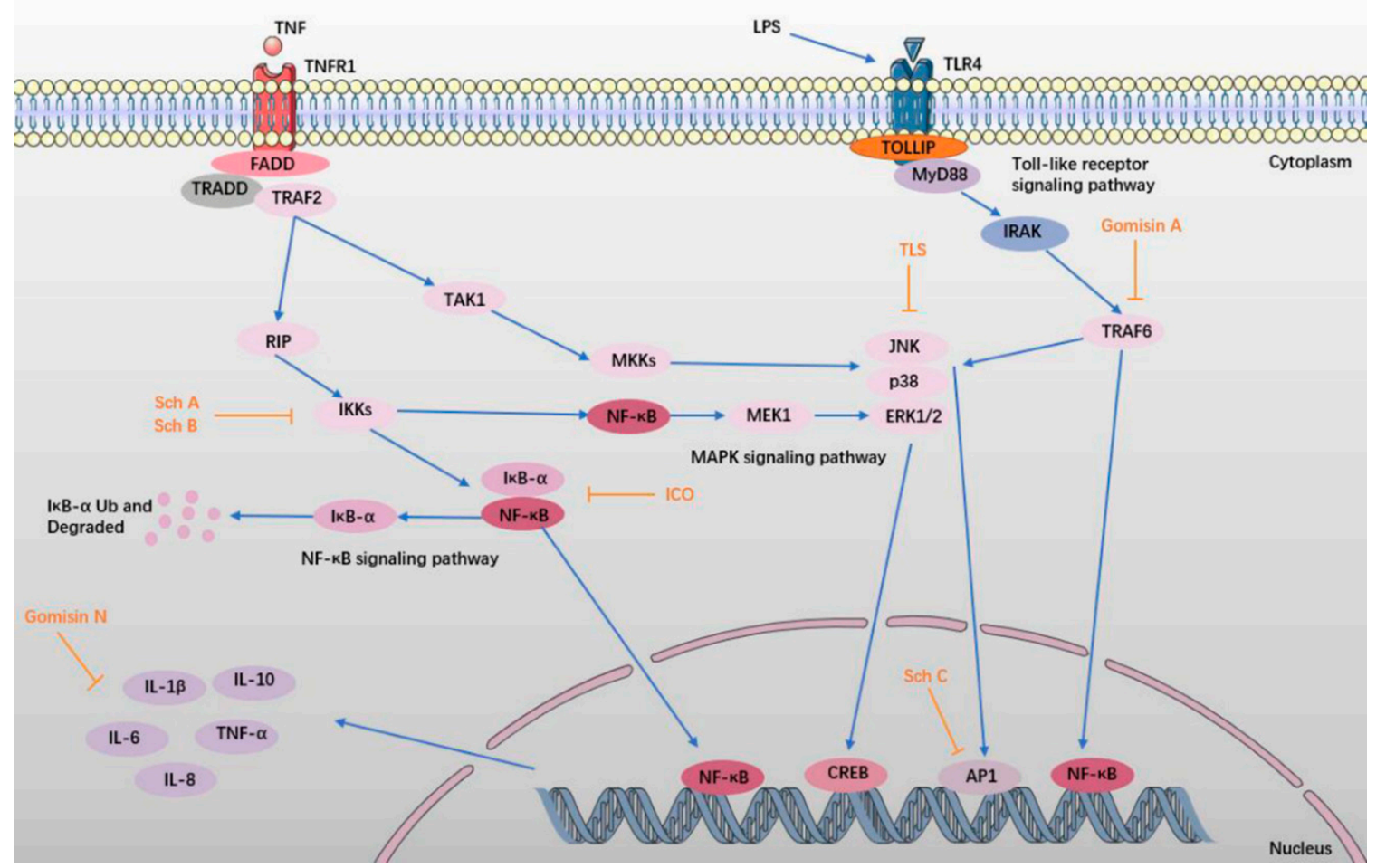

Figure 4. SCF and its active ingredients protect against inflammation in NDs. In the inflammatory response, TLR4 recognizes lipopolysaccharide (LPS), and then binds to the MyD88 Toll structure, forming a TLR-MyD active complex. Then, the complex recruits and activates the IL-1 receptor-associated kinase (IRAK), which is associated with tumor necrosis factor-associated factor 6 (TRAF6), activating the downstream mitogen-activated protein kinases (MAPK) pathway [101,102]. Meanwhile, TNFR1 binds to TNF, and interacts with receptor-interacting protein (RIP), activating the downstream inhibitory kappa B kinase (IKK) and MAPK pathway [103,104]. Phosphorylation of IKB protein leads to degradation of the protein, promotes nuclear translocation of nuclear factor- $\kappa \mathrm{B}(\mathrm{NF}-\mathrm{k} \mathrm{B})$, and transfers NF- $k B$ to the nucleus [105]. At the same time, the activation of the MAPK pathway leads to the production of activator protein-1 (AP-1), which is phosphorylated, and then enters the nucleus. Activation of NF- $\mathrm{kB}$ and AP-1 can lead to over-expression of the inflammatory factors, such as TNF- $\alpha$, IL-1 $\beta$, IL-6, IL-8, and IL-10, resulting a series of inflammatory reactions [106-109]. The protective effect of SCF and its active ingredients are shown in orange. 


\subsection{TLS}

As Zhao et al. reported, TLS protects against cognitive deficits and neurodegeneration by inhibiting the expression of JNK/p38 and BACE1 in A $\beta 1-42$-induced primary mouse neuronal cells. These results indicated that TLS could be applied as an active pharmaceutical ingredient for cognitive improvement in $\mathrm{AD}$ [26]. Furthermore, the lignans isolated from SCF, including Sch A-D, manifested beneficial activity by inhibiting the lipopolysaccharide (LPS)-induced NO release in primary murine BV2 microglia cells [29].

\subsection{Sch $A, \operatorname{Sch} B$, and $S \operatorname{ch} C$}

Song et al. reported that Sch A can exert anti-inflammatory and neuroprotective effects on LPS-induced inflammatory injury in microglia (BV2 cells) and neurons. The potential molecular mechanism may be the inhibition of the tumor necrosis factor-associated factor 6(TRAF6)- inhibitory kappa $B$ kinase (IKK) $\beta$ / nuclear translocation of nuclear factor- $k B$ (NF- $\kappa B$ ) and Janus kinase-2/signal transducer and activator of transcription-3 (Jak2/Stat3) signaling pathways [32].

Sch $B$ has been effective at inhibiting neural inflammation during in vivo and in vitro studies. Giridharan reported that Sch B modulated receptors for advanced glycation end products (RAGE), NF- $\mathrm{kB}$, and the mitogen-activated protein kinases (MAPK) signaling pathway. Moreover, an overexpression of the proteins prompting inflammation were inhibited by Sch B [37]. As Lee reported, Sch B attenuated cerebral ischemia injury in rats by suppressing the overexpression of inflammatory markers in ischemic hemispheres [39], and relieved microglial-mediated inflammatory injury by inhibiting the TLR4-dependent MyD88/IKK/NF-KB signaling pathway [36]. Moreover, Sch B showed an inhibitory effect on the LPS-induced inflammatory response by suppressing NF- $\mathrm{kB}$ activation, while activating PPAR- $\gamma$ [38].

As Park et al. reported, Sch $C$ was regarded as a natural antineuroinflammatory agent, protecting against lipoteichoic acid (LTA)-stimulated inflammation in mouse primary microglia. The results showed that Sch C suppressed NF- $\mathrm{kB}$, AP-1, JAK-STATs, and MAPK expression, and activated cAMP/PKA/CREB and Nrf-2 signaling [41].

\subsection{ICO, Gomisin A, and Gomisin N}

ICO showed a protective effect on A $\beta$-stimulated neuroinflammation in mouse primary microglia. The research indicated that ICO provided a neuroprotective function by inhibiting I $\kappa \mathrm{B}-\alpha, \mathrm{NF}-\kappa \mathrm{B}$, and the MAPK signaling pathway [49].

As one of the major dibenzocyclooctadiene lignans isolated from SCF, gomisin A manifested as a neuroprotective treatment for LPS-stimulated inflammation on N9 microglia. The potential mechanism of gomisin A was suggested to be inhibition of the TLR4-mediated NF- $\mathrm{KB}$ and MAPKs signaling pathways [50]. As Araki et al. reported, gomisin N ameliorated LPS-induced inflammation in mice and BV2 cells. The research demonstrated that an elevation of the inflammatory markers induced by LPS was inhibited by gomisin $\mathrm{N}$ treatment [52]. 
Table 4. The pharmacological data of SCF and its active ingredients in protecting against NDs by anti-inflammation effect.

\begin{tabular}{|c|c|c|c|c|c|c|}
\hline $\begin{array}{l}\text { SCF and Its Active } \\
\text { Ingredients }\end{array}$ & Study Design & Study Type & Molecular and Cellular Mechanisms of Action & Dose Range & Minimal Active Concentration & Key Reference \\
\hline \multirow{3}{*}{ TLS } & $\begin{array}{l}\mathrm{A} \beta 1-42 \text { induced } \mathrm{AD} \text { in primary } \\
\text { mouse neuronal cells }\end{array}$ & In vitro & Decreases BACE1 activity & $10,30,100 \mu \mathrm{M}$ & $10 \mu \mathrm{M}$ & [26] \\
\hline & \multicolumn{5}{|c|}{ Inhibites JNK/p38 expression } & \\
\hline & $\begin{array}{l}\text { LPS-induced inflammation in } \\
\text { microglia (BV2 cells) }\end{array}$ & In vitro & Inhibites NO level & $1,10 \mu \mathrm{M}$ & $10 \mu \mathrm{M}$ & [29] \\
\hline \multirow{4}{*}{ Sch A } & $\begin{array}{l}\text { LPS-induced inflammation in } \\
\text { microglia (BV2 cells) }\end{array}$ & In vitro & Down-regulates the NO, TNF- $\alpha$, IL-6 increasing & $10,20,50 \mu \mathrm{M}$ & $10 \mu \mathrm{M}$ & [32] \\
\hline & $\begin{array}{l}\text { Microglia-mediated inflammatory } \\
\text { injury in neurons }\end{array}$ & & Inhibites iNOS, COX-2 levels & $10,20,50 \mu \mathrm{M}$ & $20 \mu \mathrm{M}$ & \\
\hline & \multicolumn{5}{|c|}{ Inhibites TRAF6-IKK $\beta$-NF-KB pathway } & \\
\hline & \multicolumn{5}{|c|}{$\begin{array}{l}\text { Inhibites Jak2-Stat3 pathway activation and Stat3 } \\
\text { nuclear translocation }\end{array}$} & \\
\hline \multirow{9}{*}{$\operatorname{Sch} B$} & $\begin{array}{l}\mathrm{A} \beta \text {-induced neuronal dysfunction in } \\
\text { rats }\end{array}$ & In vivo & $\begin{array}{l}\text { Inhibites iNOS, COX-2, IL-1 } \beta \text {, IL-6, TNF- } \alpha \text { levels and } \\
\text { DNA damage }\end{array}$ & 25 or $50 \mathrm{mg} / \mathrm{kg}$ & $25 \mathrm{mg} / \mathrm{kg}$ & [37] \\
\hline & \multicolumn{4}{|c|}{ Inhibites RAGE, NF-kB, MAPKs } & & \\
\hline & $\begin{array}{l}\text { LPS-induced inflammation in } \\
\text { microglia (BV2 cells) }\end{array}$ & In vitro & Down-regulates TNF- $\alpha$, IL-6, IL- $1 \beta$, and PGE2 levels & $12.5,25,50 \mu \mathrm{M}$ & $12.5 \mu \mathrm{M}$ & [38] \\
\hline & \multicolumn{5}{|c|}{ Inhibites NF-kB activation } & \\
\hline & \multicolumn{5}{|c|}{ Up-ragulates the expression of PPAR- $\gamma$} & \\
\hline & $\begin{array}{l}\text { Microglial-mediated inflammatory } \\
\text { injury }\end{array}$ & In vitro & Down-regulates NO, TNF- $\alpha$, PGE2, IL-1 $\beta$, IL-6 levels & $5,10,20 \mu \mathrm{M}$ & $5 \mu \mathrm{M}$ & [36] \\
\hline & \multicolumn{5}{|c|}{ Inhibites TLR 4, MyD88, IRAK-1, TRAF-6 interaction } & \\
\hline & \multicolumn{5}{|c|}{ Inhibites IKK, NF-KB levels } & \\
\hline & $\begin{array}{l}\text { Intraluminal thread induced focal } \\
\text { cerbral ischemia in rats }\end{array}$ & In vivo & $\begin{array}{l}\text { Inhibites TNF- } \alpha \text {, IL-1 } \beta \text {, matrix metalloproteinase (MMP)-2, } \\
\text { MMP-9, OX-42 levels }\end{array}$ & $10,30 \mathrm{mg} / \mathrm{kg}$ & $10 \mathrm{mg} / \mathrm{kg}$ & [39] \\
\hline \multirow{4}{*}{$\operatorname{Sch} \mathrm{C}$} & $\begin{array}{l}\text { LTA induced inflammation in mouse } \\
\text { primary microglia }\end{array}$ & In vitro & Increases HO-1, NQO-1 levels & $1,5,10,20 \mu \mathrm{M}$ & $10 \mu \mathrm{M}$ & [41] \\
\hline & \multicolumn{5}{|c|}{ Activates cAMP, PKA, CREB, Nrf-2 levels } & \\
\hline & \multicolumn{5}{|c|}{ Attenuates ddAdo, H-89 levels } & \\
\hline & \multicolumn{5}{|c|}{$\begin{array}{c}\text { Inhibites PGE2, NO, ROS, iNOS, COX-2, } \\
\text { MMP-9 expressions }\end{array}$} & \\
\hline & & & Suppresses NF-kB, AP-1, JAK-STATs, MAPK activation & & & \\
\hline
\end{tabular}


Table 4. Cont.

\begin{tabular}{|c|c|c|c|c|c|c|}
\hline $\begin{array}{l}\text { SCF and Its Active } \\
\text { Ingredients }\end{array}$ & Study Design & Study Type & Molecular and Cellular Mechanisms of Action & Dose Range & Minimal Active Concentration & Key Reference \\
\hline ICO & $\begin{array}{l}\mathrm{A} \beta \text {-stimulated neuroinflammation } \\
\text { in mouse primary microglia }\end{array}$ & In vitro & Inhibites PGE2, NO, ROS, MMP-9 levels & $25,50,100 \mu \mathrm{M}$ & $100 \mu \mathrm{M}$ & [49] \\
\hline \multicolumn{7}{|c|}{ Inhibites iNOS, COX-2 levels } \\
\hline \multicolumn{7}{|c|}{ Inhibites I KB- $\alpha$, NF- $k B$, MAPK activities } \\
\hline Gomisin A & $\begin{array}{c}\text { LPS-stimulated inflammation N9 } \\
\text { microglia }\end{array}$ & In vitro & Suppresses iNOS, COX-2 levels & $1-100 \mu \mathrm{M}$ & $3 \mu \mathrm{M}$ & [50] \\
\hline \multicolumn{7}{|c|}{ Attenuates TNF- $\alpha$, IL- $1 \beta$ and IL- 6 levels } \\
\hline & & & $\begin{array}{l}\text { Inhibited TAK1-IKKa/b-IkB -NF- } \mathrm{kB} \text { and MAPKs } \\
\text { inflammatory signaling pathways }\end{array}$ & $30-100 \mu \mathrm{M}$ & $30 \mu \mathrm{M}$ & \\
\hline \multicolumn{7}{|c|}{ Inhibited TLR4 expression } \\
\hline Gomisin N & $\begin{array}{l}\text { LPS-induced inflammatory and } \\
\text { depressive symptoms in mice }\end{array}$ & In vivo & Inhibites iNOS, COX-2, IL-1 $\beta$, IL-6, TNF- $\alpha$ levels & $100 \mathrm{mg} / \mathrm{kg}$ & $100 \mathrm{mg} / \mathrm{kg}$ & [52] \\
\hline \multicolumn{7}{|c|}{ Increases c-Fos immunopositive cells number } \\
\hline & $\begin{array}{l}\text { LPS-induced inflammation in } \\
\text { microglia (BV2 cells) }\end{array}$ & In vitro & Inhibites iNOS, COX-2, IL-1 $\beta$, IL-6, TNF- $\alpha$ levels & $1.56-50 \mu \mathrm{M}$ & $25 \mu \mathrm{M}$ & \\
\hline
\end{tabular}




\section{Regulation of Neurotransmitters}

The emotional processing and behavioral anxiety are determined by the reciprocal relationship between the central nervous system and the endocrine signals. Peptide hormones are increasingly recognized for their effects on anxiety-like behavior and reward [110]. The neurobiological bases of depression and anxiety disorders are not fully understood and the currently available treatments are not always effective [111]. In recent years, the disorders of neurotransmitters, including norepinephrine (NE), 5-hydroxytryptamine (5-HT), dopamine (DA), and gamma-aminobutyric acid (GABA) have been reported to lead to significant changes in neurodegenerative diseases and induce anxiety, depression, arousal, and alarm [112-114]. They are involved in the pathophysiological bases of these diseases and provide benefits in their treatment through their diverse functions $[115,116]$. Despite this, antidepressant and anxiolytic drug development has largely stalled [117].

SCF was demonstrated to ameliorate 4-chloro-dl-phenylalanine (PCPA) induced insomnia in rats by regulating the expression of brain neurotransmitters and their metabolites through its sedative-hypnotic effects [25]. Furthermore, SCF was used as an efficient treatment for anxiety-like behavior induced by ethanol withdrawal. The results showed that it attenuated anxiety by significantly downregulating the elevation of norepinephrine (NE) and its metabolite in the hypothalamic paraventricular nucleus [24]. According to the latest report, $\mathrm{SCH}$ showed a neuroprotective effect by ameliorating learning and memory impairments in APP/PSI transgenic mice. The mechanism was suggested to be regulation of neurotransmitters and their metabolites in the brain. The results indicated that SCH could be applied as an active pharmaceutical compound for neurodegenerative diseases such as PD and AD [46]. The pharmacological data are shown in Table 5.

\section{Modulation of BDNF Related Pathways}

As a growth factor dynamically expressed in the brain across postnatal development, BDNF regulates neuronal differentiation and synaptic plasticity. It is acknowledged that decreased BDNF levels lead to altered neural plasticity, contributing to disease [118]. The mechanism of BDNF release appears to be related to synaptic sprouting and strengthened synaptic connections [119]. Nowadays, depression and anxiety are becoming major burdens to society, affecting as much as $7 \%$ of the world's population [120]. BDNF has been introduced to treatment-resistant depression and it has been identified as a therapeutic target for depression [121,122]. Furthermore, it is a distinct marker of stress adaptation, extinction of fear, and neuroimmune response [123-125].

Yan et al. reported that SCF could improve a depression-like emotional state and associated cognitive deficits in mice with chronic unpredictable mild stress (CUMS). The mechanism was proven to regulate BDNF expression in the hippocampus as well as upregulate the TrkB/CREB/ERK and PI3K/Akt/GSK-3 $\beta$ pathways [22,23]. Moreover, Yuan et al. reported that nigranoic acid (SBB1, 3,4-secocycloartene triterpenoid) manifested beneficial effects in terms of enhancing mental and intellectual functions by increasing BDNF and c-fos expression in NGF-differentiated PC12 cells [53]. The pharmacological data are shown in Table 6. 
Table 5. The pharmacological data of SCF and its active ingredients in protecting against NDs by regulating neurotransmitters. PCPA—4-chloro-dl-phenylalanine; GABA—gamma-aminobutyric acid; DA—dopamine.

\begin{tabular}{|c|c|c|c|c|c|c|}
\hline $\begin{array}{c}\text { SCF and its } \\
\text { Active Ingredients }\end{array}$ & Study Design & Study Type & Molecular and Cellular Mechanisms of Action & Dose Range & Minimal Active Concentration & Key Reference \\
\hline \multirow{3}{*}{ SCF } & $\begin{array}{l}\text { Ethanol withdrawal induced } \\
\text { anxiety-like behavior }\end{array}$ & In vivo & Decreases NE and its metabolite & & & [24] \\
\hline & PCPA induced insomnia in rat & In vivo & $\begin{array}{l}\text { Reduces the elevation of GABA, NE, DA, } \\
\text { DOPAC, HVA }\end{array}$ & $7.5 \mathrm{~g} / \mathrm{kg}$ & $7.5 \mathrm{~g} / \mathrm{kg}$ & [25] \\
\hline & \multicolumn{6}{|c|}{ Increases 5-HT, 5-HIAA levels } \\
\hline \multirow{3}{*}{$\mathrm{SCH}$} & $\begin{array}{l}\text { APP/PS1 transgenic mice } \\
\text { (induced } \mathrm{AD} \text { ) }\end{array}$ & In vivo & Ameliorated the cognitive impairment & $2 \mathrm{mg} / \mathrm{kg}$ & $2 \mathrm{mg} / \mathrm{kg}$ & [46] \\
\hline & \multicolumn{5}{|c|}{ Decreases $A \beta$ deposition in the hippocampus } & \\
\hline & & & $\begin{array}{c}\text { Regulates serotonin, 5-HIAA, DA, NE, } \\
\gamma \text {-aminobutyric acid, glutamic acid, homovanillic } \\
\text { acid, 3,4-dihydroxyphenylacetic acid and } \\
\text { acetylcholine levels }\end{array}$ & & & \\
\hline
\end{tabular}

Table 6. The pharmacological data of SCF and its active ingredients in protecting against NDs by modulating BDNF related pathways. CUMS—chronic unpredictable mild stress.

\begin{tabular}{|c|c|c|c|c|c|c|}
\hline $\begin{array}{c}\text { SCF and Its } \\
\text { Active Ingredients }\end{array}$ & Study Design & Study Type & Molecular and Cellular Mechanisms of Action & Dose Range & Minimal Active Concentration & Key Reference \\
\hline \multirow{4}{*}{ SCF } & $\begin{array}{c}\text { Corticosterone induced } \\
\text { depressive-like behavior in mice }\end{array}$ & In vivo & Up-ragulates BDNF/TrkB/CREB & $300,600 \mathrm{mg} / \mathrm{kg}$ & $600 \mathrm{mg} / \mathrm{kg}$ & [22] \\
\hline & $\begin{array}{l}\text { CUMS-induced depression and } \\
\text { cognitive impairment in mice }\end{array}$ & In vivo & Increases BDNF levels in hippocampus & $600-1200 \mathrm{mg} / \mathrm{kg}$ & $600 \mathrm{mg} / \mathrm{kg}$ & [23] \\
\hline & & & Up-regulates TrkB/CREB/ERK & & & \\
\hline & & & Up-regulates PI3K/Akt/GSK-3 $\beta$ & & & \\
\hline \multirow{3}{*}{ Nigranoic acid } & NGF-differentiated PC12 cells & In vitro & Increases BDNF, c-fos mRNA & $1,10,50 \mu \mathrm{M}$ & $50 \mu \mathrm{M}$ & [53] \\
\hline & & & Increases cytoplasmic $\mathrm{Ca}^{2+}, \mathrm{NO}$ levels & & & \\
\hline & & & Activates ERK1/2, CaMKII levels & & & \\
\hline
\end{tabular}




\section{Conclusions and Perspectives for Future Work}

SCF and its active ingredients manifest a protective effect on NDs by attenuating injury induced by overoxidative stress, apoptosis, inflammation, and neurotransmitter disorders. The most active ingredients in SCF, lignans, share the same physiologically active structure as biphenyl cycloalkenol, whose parent nucleus is biphenyl cyclooctadiene [126]. Biphenyl cyclooctadiene has a biphenyl structure, as well as the eight-membered ring structure of biphenyl and side-chain synthesis. Given its many structural forms and stereoisomers, it is acknowledged as the key structure displaying antioxidation, antiapoptosis, and antiviral effects [127]. In future studies, attention should be paid to the components of the key active structures, so as to screen out lead compounds. The structure of the lead compounds should be optimized to enhance metabolic stability and improve bioavailability, in order to provide new candidates for the clinical treatment of NDs.

The pathogenesis of NDs has been further elucidated in recent years, such as the mitochondrial mechanism of neuroglial crosstalk after stroke [128], phagocytosis of reactive astrocytes following brain ischemia [129], purinergic signaling in reactive astrocytes of AD [130], endothelial cytoskeletal reorganization in blood-brain barrier disruption [131], cerebral cavernous malformations in stroke, and seizure $[132,133]$. Furthermore, more therapeutic targets of NDs have been discovered recently, such as TRPA1 [134], IL-27 [135], TIM-3 [136], tau [137], and histamine H3 receptor [138]. As biologically active drugs, in future work, SCF and its active ingredients should be applied to many more target-screening models.

Acknowledgments: This work was supported by the National Natural Science Foundation of China (81703840) and a grant from the National Science and Technology Major Project (Grant No. 2014ZX09201021-009).

Conflicts of Interest: The authors declare no conflict of interest.

\section{References}

1. Birbeck, G.L.; Meyer, A.C.; Ogunniyi, A. Nervous system disorders across the life course in resource-limited settings. Nature 2015, 527, S167-S171. [CrossRef] [PubMed]

2. Khatib, R.; Jawaada, A.M.; Arevalo, Y.A.; Hamed, H.K.; Mohammed, S.H.; Huffman, M.D. Implementing Evidence-Based Practices for Acute Stroke Care in Low- and Middle-Income Countries. Curr. Atheroscler. Rep. 2017, 19, 61. [CrossRef] [PubMed]

3. National Center for Cardiovascular Disease. Report on Cardiovascular Diseases in China (2016); Encyclopedia of China Publishing House: Beijing, China, 2017.

4. Lindley, R.I. Stroke Prevention in the Very Elderly. Stroke 2018, 49, 796-802. [CrossRef] [PubMed]

5. Madsen, T.E.; Howard, V.J.; Jimenez, M.; Rexrode, K.M.; Acelajado, M.C.; Kleindorfer, D.; Chaturvedi, S. Impact of Conventional Stroke Risk Factors on Stroke in Women: An Update. Stroke 2018, 49, 536-542. [CrossRef] [PubMed]

6. Demel, S.L.; Kittner, S.; Ley, S.H.; McDermott, M.; Rexrode, K.M. Stroke Risk Factors Unique to Women. Stroke 2018, 49, 518-523. [CrossRef] [PubMed]

7. Powers, W.J.; Rabinstein, A.A.; Ackerson, T.; Adeoye, O.M.; Bambakidis, N.C.; Becker, K.; Biller, J.; Brown, M.; Demaerschalk, B.M.; Hoh, B.; et al. Guidelines for the Early Management of Patients with Acute Ischemic Stroke: A Guideline for Healthcare Professionals From the American Heart Association/American Stroke Association. Stroke 2018, 49, e46-e110. [CrossRef] [PubMed]

8. Vinters, H.V.; Zarow, C.; Borys, E.; Whitman, J.D.; Tung, S.; Ellis, W.G.; Zheng, L.; Chui, H.C. Review: Vascular dementia: Clinicopathologic and genetic considerations. Neuropathol. Appl. Neurobiol. 2018, 44, 247-266. [CrossRef] [PubMed]

9. Cacabelos, R.; Meyyazhagan, A.; Carril, J.C.; Cacabelos, P.; Teijido, O. Pharmacogenetics of Vascular Risk Factors in Alzheimer's Disease. J. Pers. Med. 2018, 8, 3. [CrossRef] [PubMed]

10. Lu, Y.; Chen, D.F. Analysis of Schisandra chinensis and Schisandra sphenanthera. J. Chromatogr. A 2009, 1216, 1980-1990. [CrossRef] [PubMed] 
11. Szopa, A.; Ekiert, R.; Ekiert, H. Current knowledge of Schisandra chinensis (Turcz.) Baill. (Chinese magnolia vine) as a medicinal plant species: A review on the bioactive components, pharmacological properties, analytical and biotechnological studies. Phytochem. Rev. 2017, 16, 195-218. [CrossRef] [PubMed]

12. Liu, H.; Lai, H.; Jia, X.; Liu, J.; Zhang, Z.; Qi, Y.; Zhang, J.; Song, J.; Wu, C.; Zhang, B.; et al. Comprehensive chemical analysis of Schisandra chinensis by HPLC-DAD-MS combined with chemometrics. Phytomedicine 2013, 20, 1135-1143. [CrossRef] [PubMed]

13. Cheng, Z.; Yang, Y.; Liu, Y.; Liu, Z.; Zhou, H.; Hu, H. Two-steps extraction of essential oil, polysaccharides and biphenyl cyclooctene lignans from Schisandra chinensis Baill fruits. J. Pharm. Biomed. Anal. 2014, 96, 162-169. [CrossRef] [PubMed]

14. Zhang, M.; Wu, H.; Guo, F.; Yu, Y.; Wei, J.; Geng, Y.; Wang, S.; Li, S.; Yang, H. Identification of active components in Yixinshu Capsule with protective effects against myocardial dysfunction on human induced pluripotent stem cell-derived cardiomyocytes by an integrative approach. Mol. Biosyst. 2017, 13, 1469-1480. [CrossRef] [PubMed]

15. Zhang, W.; Sun, Z.; Meng, F. Schisandrin B Ameliorates Myocardial Ischemia/Reperfusion Injury Through Attenuation of Endoplasmic Reticulum Stress-Induced Apoptosis. Inflammation 2017, 40, $1903-1911$. [CrossRef] [PubMed]

16. Wat, E.; Ng, C.F.; Wong, E.C.; Koon, C.M.; Lau, C.P.; Cheung, D.W.; Fung, K.P.; Lau, C.B.; Leung, P.C. The hepatoprotective effect of the combination use of Fructus Schisandrae with statin-A preclinical evaluation. J. Ethnopharmacol. 2016, 178, 104-114. [CrossRef] [PubMed]

17. Casarin, E.; Dall'Acqua, S.; Smejkal, K.; Slapetova, T.; Innocenti, G.; Carrara, M. Molecular mechanisms of antiproliferative effects induced by Schisandra-derived dibenzocyclooctadiene lignans (+)-deoxyschisandrin and (-)-gomisin N in human tumour cell lines. Fitoterapia 2014, 98, 241-247. [CrossRef] [PubMed]

18. Xu, L.; Grandi, N.; Del Vecchio, C.; Mandas, D.; Corona, A.; Piano, D.; Esposito, F.; Parolin, C.; Tramontano, E. From the traditional Chinese medicine plant Schisandra chinensis new scaffolds effective on HIV-1 reverse transcriptase resistant to non-nucleoside inhibitors. J Microbiol. 2015, 53, 288-293. [CrossRef] [PubMed]

19. Liu, Z.; Guo, F.; Wang, Y.; Li, C.; Zhang, X.; Li, H.; Diao, L.; Gu, J.; Wang, W.; Li, D.; et al. BATMAN-TCM: A Bioinformatics Analysis Tool for Molecular mechANism of Traditional Chinese Medicine. Sci. Rep. 2016, 6, 21146. [CrossRef] [PubMed]

20. Zhai, J.; Zhang, F.; Gao, S.; Chen, L.; Feng, G.; Yin, J.; Chen, W. Schisandra chinensis extract decreases chloroacetaldehyde production in rats and attenuates cyclophosphamide toxicity in liver, kidney and brain. J. Ethnopharmacol. 2018, 210, 223-231. [CrossRef] [PubMed]

21. Yang, B.Y.; Tan, J.Y. A UPLC-TOF/MS-based metabolomics study of rattan stems of Schisandra chinensis effects on Alzheimer's disease rats model. Biomed. Chromatogr. 2018, 32. [CrossRef] [PubMed]

22. Yan, T.; Xu, M.; Wan, S.; Wang, M.; Wu, B.; Xiao, F.; Bi, K.; Jia, Y. Schisandra chinensis produces the antidepressant-like effects in repeated corticosterone-induced mice via the BDNF/TrkB/CREB signaling pathway. Psychiatry Res. 2016, 243, 135-142. [CrossRef] [PubMed]

23. Yan, T.; He, B.; Wan, S.; Xu, M.; Yang, H.; Xiao, F.; Bi, K.; Jia, Y. Antidepressant-like effects and cognitive enhancement of Schisandra chinensis in chronic unpredictable mild stress mice and its related mechanism. Sci. Rep. 2017, 7, 6903. [CrossRef] [PubMed]

24. Wu, Y.; Zhao, Z.; Yang, Y.; Yang, X.; Jang, E.Y.; Schilaty, N.D.; Hedges, D.M.; Kim, S.C.; Cho, I.J.; Zhao, R. Effects of the aqueous extract of Schizandra chinensis fruit on ethanol withdrawal-induced anxiety in rats. Chin. Med. J. 2014, 127, 1935-1940. [PubMed]

25. Wei, B.; Li, Q.; Fan, R.; Su, D.; Chen, X.; Jia, Y.; Bi, K. Determination of monoamine and amino acid neurotransmitters and their metabolites in rat brain samples by UFLC-MS/MS for the study of the sedative-hypnotic effects observed during treatment with S. chinensis. J. Pharm. Biomed. Anal. 2014, 88, 416-422. [CrossRef] [PubMed]

26. Zhao, X.; Liu, C.; Xu, M.; Li, X.; Bi, K.; Jia, Y. Total Lignans of Schisandra chinensis Ameliorates Abeta1-42-Induced Neurodegeneration with Cognitive Impairment in Mice and Primary Mouse Neuronal Cells. PLoS ONE 2016, 11, e0152772. [CrossRef]

27. Yan, T.; Shang, L.; Wang, M.; Zhang, C.; Zhao, X.; Bi, K.; Jia, Y. Lignans from Schisandra chinensis ameliorate cognition deficits and attenuate brain oxidative damage induced by D-galactose in rats. Metab. Brain Dis. 2016, 31, 653-661. [CrossRef] [PubMed] 
28. Jiang, E.P.; Wang, S.Q.; Wang, Z.; Yu, C.R.; Chen, J.G.; Yu, C.Y. Effect of Schisandra chinensis lignans on neuronal apoptosis and p-AKT expression of rats in cerebral ischemia injury model. Zhongguo Zhong Yao Za Zhi 2014, 39, 1680-1684. [PubMed]

29. Hu, D.; Yang, Z.; Yao, X.; Wang, H.; Han, N.; Liu, Z.; Wang, Y.; Yang, J.; Yin, J. Dibenzocyclooctadiene lignans from Schisandra chinensis and their inhibitory activity on NO production in lipopolysaccharide-activated microglia cells. Phytochemistry 2014, 104, 72-78. [CrossRef] [PubMed]

30. Hu, D.; Li, C.; Han, N.; Miao, L.; Wang, D.; Liu, Z.; Wang, H.; Yin, J. Deoxyschizandrin isolated from the fruits of Schisandra chinensis ameliorates $\mathrm{A} \beta_{1-42}$-induced memory impairment in mice. Planta Med. 2012, 78, 1332-1336. [CrossRef] [PubMed]

31. Wang, C.P.; Li, G.C.; Shi, Y.W.; Zhang, X.C.; Li, J.L.; Wang, Z.W.; Ding, F.; Liang, X.M. Neuroprotective effect of schizandrin A on oxygen and glucose deprivation/reperfusion-induced cell injury in primary culture of rat cortical neurons. J. Physiol. Biochem. 2014, 70, 735-747. [CrossRef] [PubMed]

32. Song, F.; Zeng, K.; Liao, L.; Yu, Q.; Tu, P.; Wang, X. Schizandrin A Inhibits Microglia-Mediated Neuroninflammation through Inhibiting TRAF6-NF-kappaB and Jak2-Stat3 Signaling Pathways. PLoS ONE. 2016, 11, e0149991. [CrossRef]

33. Giridharan, V.V.; Thandavarayan, R.A.; Sato, S.; Ko, K.M.; Konishi, T. Prevention of scopolamine-induced memory deficits by schisandrin B, an antioxidant lignan from Schisandra chinensis in mice. Free Radic. Res. 2011, 45, 950-958. [CrossRef] [PubMed]

34. Chen, N.; Chiu, P.Y.; Ko, K.M. Schisandrin B enhances cerebral mitochondrial antioxidant status and structural integrity, and protects against cerebral ischemia/reperfusion injury in rats. Biol. Pharm. Bull. 2008, 31, 1387-1391. [CrossRef] [PubMed]

35. Xu, M.; Dong, Y.; Wan, S.; Yan, T.; Cao, J.; Wu, L.; Bi, K.; Jia, Y. Schisantherin B ameliorates Abeta1-42-induced cognitive decline via restoration of GLT-1 in a mouse model of Alzheimer's disease. Physiol. Behav. 2016, 167, 265-273. [CrossRef] [PubMed]

36. Zeng, K.W.; Zhang, T.; Fu, H.; Liu, G.X.; Wang, X.M. Schisandrin B exerts anti-neuroinflammatory activity by inhibiting the Toll-like receptor 4-dependent MyD88/IKK/NF-kappaB signaling pathway in lipopolysaccharide-induced microglia. Eur. J. Pharmacol. 2012, 692, 29-37. [CrossRef] [PubMed]

37. Giridharan, V.V.; Thandavarayan, R.A.; Arumugam, S.; Mizuno, M.; Nawa, H.; Suzuki, K.; Ko, K.M.; Krishnamurthy, P.; Watanabe, K.; Konishi, T. Schisandrin B Ameliorates ICV-Infused Amyloid beta Induced Oxidative Stress and Neuronal Dysfunction through Inhibiting RAGE/NF-kappaB/MAPK and Up-Regulating HSP/Beclin Expression. PLoS ONE 2015, 10, e0142483. [CrossRef] [PubMed]

38. Liu, N.; Zheng, J.X.; Zhuang, Y.S.; Zhou, Z.K.; Zhao, J.H.; Yang, L. Anti-Inflammatory Effects of Schisandrin B on LPS-Stimulated BV2 Microglia via Activating PPAR-gamma. Inflammation 2017, 40, 1006-1011. [CrossRef] [PubMed]

39. Lee, T.H.; Jung, C.H.; Lee, D.H. Neuroprotective effects of Schisandrin B against transient focal cerebral ischemia in Sprague-Dawley rats. Food Chem Toxicol. 2012, 50, 4239-4245. [CrossRef] [PubMed]

40. Tang, M.; Zhang, X.; Shi, Y.; Wang, D.; Gu, Y.; Li, S.; Liang, X.; Wang, Z.; Wang, C. Protection of seven dibenzocyclooctadiene lignans from Schisandra chinensis against serum and glucose deprivation injury in SH-SY5Y cells. Cell Biol. Int. 2015, 39, 1418-1424. [CrossRef] [PubMed]

41. Park, S.Y.; Park, S.J.; Park, T.G.; Rajasekar, S.; Lee, S.J.; Choi, Y.W. Schizandrin C exerts anti-neuroinflammatory effects by upregulating phase II detoxifying/antioxidant enzymes in microglia. Int. Immunopharmacol. 2013, 17, 415-426. [CrossRef] [PubMed]

42. Zhang, L.Q.; Sa, F.; Chong, C.M.; Wang, Y.; Zhou, Z.Y.; Chang, R.C.; Chan, S.W.; Hoi, P.M.; Yuen Lee, S.M. Schisantherin A protects against 6-OHDA-induced dopaminergic neuron damage in zebrafish and cytotoxicity in SH-SY5Y cells through the ROS/NO and AKT/GSK3beta pathways. Oxid. Med. Cell. Longev. 2015, 170, 8-15. [CrossRef] [PubMed]

43. Li, X.; Zhao, X.; Xu, X.; Mao, X.; Liu, Z.; Li, H.; Guo, L.; Bi, K.; Jia, Y. Schisantherin A recovers Abeta-induced neurodegeneration with cognitive decline in mice. Physiol. Behav. 2014, 132, 10-16. [CrossRef] [PubMed]

44. Sa, F.; Zhang, L.Q.; Chong, C.M.; Guo, B.J.; Li, S.; Zhang, Z.J.; Zheng, Y.; Hoi, P.M.; Lee, S.M. Discovery of novel anti-parkinsonian effect of schisantherin A in in vitro and in vivo. Neurosci. Lett. 2015, 593, 7-12. [CrossRef] [PubMed] 
45. Hu, D.; Cao, Y.; He, R.; Han, N.; Liu, Z.; Miao, L.; Yin, J. Schizandrin, an antioxidant lignan from Schisandra chinensis, ameliorates Abeta1-42-induced memory impairment in mice. Oxid. Med. Cell. Longev. 2012, 2012, 721721. [CrossRef] [PubMed]

46. Wei, B.B.; Liu, M.Y.; Chen, Z.X.; Wei, M.J. Schisandrin ameliorates cognitive impairment and attenuates Abeta deposition in APP/PS1 transgenic mice: Involvement of adjusting neurotransmitters and their metabolite changes in the brain. Acta Pharmacol. Sin. 2018. [CrossRef] [PubMed]

47. Park, S.Y.; Son, B.G.; Park, Y.H.; Kim, C.M.; Park, G.; Choi, Y.W. The neuroprotective effects of alpha-iso-cubebene on dopaminergic cell death: Involvement of CREB/Nrf-2 signaling. Neurochem. Res. 2014, 39, 1759-1766. [CrossRef] [PubMed]

48. Song, S.H.; Choi, S.M.; Kim, J.E.; Sung, J.E.; Lee, H.A.; Choi, Y.H.; Bae, C.J.; Choi, Y.W.; Hwang, D.Y. alpha-Isocubebenol alleviates scopolamine-induced cognitive impairment by repressing acetylcholinesterase activity. Neurosci. Lett. 2017, 638, 121-128. [CrossRef] [PubMed]

49. Park, S.Y.; Park, S.J.; Park, N.J.; Joo, W.H.; Lee, S.J.; Choi, Y.W. alpha-Iso-cubebene exerts neuroprotective effects in amyloid beta stimulated microglia activation. Neurosci. Lett. 2013, 555, 143-148. [CrossRef] [PubMed]

50. Wang, X.; Hu, D.; Zhang, L.; Lian, G.; Zhao, S.; Wang, C.; Yin, J.; Wu, C.; Yang, J. Gomisin A inhibits lipopolysaccharide-induced inflammatory responses in N9 microglia via blocking the NF-kappaB/MAPKs pathway. Food Chem. Toxicol. 2014, 63, 119-127. [CrossRef] [PubMed]

51. Zhai, J.; Zhang, F.; Gao, S.; Chen, L.; Feng, G.; Yin, J.; Chen, W. Time- and NADPH-Dependent Inhibition on CYP3A by Gomisin A and the Pharmacokinetic Interactions between Gomisin A and Cyclophosphamide in Rats. Molecules 2017, 22, 1298. [CrossRef] [PubMed]

52. Araki, R.; Hiraki, Y.; Nishida, S.; Inatomi, Y.; Yabe, T. Gomisin N ameliorates lipopolysaccharide-induced depressive-like behaviors by attenuating inflammation in the hypothalamic paraventricular nucleus and central nucleus of the amygdala in mice. J. Pharmacol. Sci. 2016, 132, 138-144. [CrossRef] [PubMed]

53. Yuan, X.X.; Yang, L.P.; Yang, Z.L.; Xiao, W.L.; Sun, H.D.; Wu, G.S.; Luo, H.R. Effect of nigranoic acid on $\mathrm{Ca}(2)(+)$ influx and its downstream signal mechanism in NGF-differentiated PC12 cells. J. Ethnopharmacol. 2014, 153, 725-731. [CrossRef] [PubMed]

54. Skovierova, H.; Vidomanova, E.; Mahmood, S.; Sopkova, J.; Drgova, A.; Cervenova, T.; Halasova, E.; Lehotsky, J. The Molecular and Cellular Effect of Homocysteine Metabolism Imbalance on Human Health. Int. J. Mol. Sci. 2016, 17, 1733. [CrossRef] [PubMed]

55. Najjar, S.; Pahlajani, S.; De Sanctis, V.; Stern, J.N.H.; Najjar, A.; Chong, D. Neurovascular Unit Dysfunction and Blood-Brain Barrier Hyperpermeability Contribute to Schizophrenia Neurobiology: A Theoretical Integration of Clinical and Experimental Evidence. Front. Psychiatry 2017, 8, 83. [CrossRef] [PubMed]

56. Bar-Or, D.; Bar-Or, R.; Rael, L.T.; Brody, E.N. Oxidative stress in severe acute illness. Redox Biol. 2015, 4, 340-345. [CrossRef] [PubMed]

57. Chomova, M.; Zitnanova, I. Look into brain energy crisis and membrane pathophysiology in ischemia and reperfusion. Stress 2016, 19, 341-348. [CrossRef] [PubMed]

58. Duan, X.; Wen, Z.; Shen, H.; Shen, M.; Chen, G. Intracerebral Hemorrhage, Oxidative Stress, and Antioxidant Therapy. Oxid. Med. Cell. Longev. 2016, 2016, 1203285. [CrossRef] [PubMed]

59. Nabavi, S.F.; Dean, O.M.; Turner, A.; Sureda, A.; Daglia, M.; Nabavi, S.M. Oxidative stress and post-stroke depression: Possible therapeutic role of polyphenols? Curr. Med. Chem. 2015, 22, 343-351. [CrossRef] [PubMed]

60. Zhao, M.; Zhu, P.; Fujino, M.; Zhuang, J.; Guo, H.; Sheikh, I.; Zhao, L.; Li, X.K. Oxidative Stress in Hypoxic-Ischemic Encephalopathy: Molecular Mechanisms and Therapeutic Strategies. Int. J. Mol. Sci. 2016, 17, 2078. [CrossRef] [PubMed]

61. Fang, C.; Gu, L. The Interrelation between Reactive Oxygen Species and Autophagy in Neurological Disorders. Oxid. Med. Cell. Longev. 2017, 2017, 8495160. [CrossRef] [PubMed]

62. Prentice, H.; Modi, J.P.; Wu, J.Y. Mechanisms of Neuronal Protection against Excitotoxicity, Endoplasmic Reticulum Stress, and Mitochondrial Dysfunction in Stroke and Neurodegenerative Diseases. Oxid. Med. Cell. Longev. 2015, 2015, 964518. [CrossRef] [PubMed]

63. Nosaka, N.; Okada, A.; Tsukahara, H. Effects of Therapeutic Hypothermia for Neuroprotection from the Viewpoint of Redox Regulation. J. Immunol. Res. 2017, 71, 1-9. [CrossRef] 
64. Morris, G.; Anderson, G.; Dean, O.; Berk, M.; Galecki, P.; Martin-Subero, M.; Maes, M. The glutathione system: A new drug target in neuroimmune disorders. Mol. Neurobiol. 2014, 50, 1059-1084. [CrossRef] [PubMed]

65. Dringen, R.; Brandmann, M.; Hohnholt, M.C.; Blumrich, E.M. Glutathione-Dependent Detoxification Processes in Astrocytes. Neurochem. Res. 2015, 40, 2570-2582. [CrossRef] [PubMed]

66. Hensley, K.; Denton, T.T. Alternative functions of the brain transsulfuration pathway represent an underappreciated aspect of brain redox biochemistry with significant potential for therapeutic engagement. Free Radic. Biol. Med. 2015, 78, 123-134. [CrossRef] [PubMed]

67. Lee, S.Y.; Lee, S.J.; Han, C.; Patkar, A.A.; Masand, P.S.; Pae, C.U. Oxidative/nitrosative stress and antidepressants: Targets for novel antidepressants. Prog. Neuropsychopharmacol. Biol. Psychiatry 2013, 46, 224-235. [CrossRef] [PubMed]

68. Muyderman, H.; Chen, T. Mitochondrial dysfunction in amyotrophic lateral sclerosis-A valid pharmacological target? Br. J. Pharmacol. 2014, 171, 2191-2205. [CrossRef] [PubMed]

69. Huang, T.T.; Leu, D.; Zou, Y. Oxidative stress and redox regulation on hippocampal-dependent cognitive functions. Arch. Biochem. Biophys. 2015, 576, 2-7. [CrossRef] [PubMed]

70. Liu, Z.; Zhou, T.; Ziegler, A.C.; Dimitrion, P.; Zuo, L. Oxidative Stress in Neurodegenerative Diseases: From Molecular Mechanisms to Clinical Applications. Oxid. Med. Cell. Longev. 2017, 2017, 2525967. [CrossRef] [PubMed]

71. Angelova, P.R.; Abramov, A.Y. Role of mitochondrial ROS in the brain: From physiology to neurodegeneration. FEBS Lett. 2018, 592, 692-702. [CrossRef] [PubMed]

72. Wang, Q.-C.; Zheng, Q.; Tan, H.; Zhang, B.; Li, X.; Yang, Y.; Yu, J.; Liu, Y.; Chai, H.; Wang, X.; et al. TMCO1 Is an ER Ca ${ }^{2+}$ Load-Activated $\mathrm{Ca}^{2+}$ Channel. Cell 2016, 165, 1454-1466. [CrossRef] [PubMed]

73. Paula-Lima, A.C.; Adasme, T.; Hidalgo, C. Contribution of $\mathrm{Ca}^{2+}$ release channels to hippocampal synaptic plasticity and spatial memory: Potential redox modulation. Antioxid. Redox Signal. 2014, 21, 892-914. [CrossRef] [PubMed]

74. Luo, J. Autophagy and ethanol neurotoxicity. Autophagy 2014, 10, 2099-2108. [CrossRef] [PubMed]

75. Vasilyeva, L.N.; Podgornaya, O.I.; Bespalov, V.G. Nucleosome fracton of extracellular dna as the index of apoptosis. Tsitologiia 2015, 57, 87-94. [PubMed]

76. Radak, D.; Katsiki, N.; Resanovic, I.; Jovanovic, A.; Sudar-Milovanovic, E.; Zafirovic, S.; Mousad, S.A.; Isenovic, E.R. Apoptosis and Acute Brain Ischemia in Ischemic Stroke. Curr. Vasc. Pharmacol. 2017, 15, 115-122. [CrossRef] [PubMed]

77. Zhao, S.C.; Ma, L.S.; Chu, Z.H.; Xu, H.; Wu, W.Q.; Liu, F. Regulation of microglial activation in stroke. Acta Pharmacol. Sin. 2017, 38, 445-458. [CrossRef] [PubMed]

78. Ulamek-Koziol, M.; Pluta, R.; Januszewski, S.; Kocki, J.; Bogucka-Kocka, A.; Czuczwar, S.J. Expression of Alzheimer's disease risk genes in ischemic brain degeneration. Pharmacol. Rep. 2016, 68, 1345-1349. [CrossRef] [PubMed]

79. Kim, T.; Vemuganti, R. Mechanisms of Parkinson's disease-related proteins in mediating secondary brain damage after cerebral ischemia. J. Cereb. Blood Flow Metab. 2017, 37, 1910-1926. [CrossRef] [PubMed]

80. Dawson, T.M.; Dawson, V.L. Mitochondrial Mechanisms of Neuronal Cell Death: Potential Therapeutics. Annu. Rev. Pharmacol. Toxicol. 2017, 57, 437-454. [CrossRef] [PubMed]

81. Thornton, C.; Hagberg, H. Role of mitochondria in apoptotic and necroptotic cell death in the developing brain. Clin. Chim. Acta 2015, 451, 35-38. [CrossRef] [PubMed]

82. Garcia de la Cadena, S.; Massieu, L. Caspases and their role in inflammation and ischemic neuronal death. Focus on caspase-12. Apoptosis 2016, 21, 763-777. [CrossRef] [PubMed]

83. Dekkers, M.P.; Nikoletopoulou, V.; Barde, Y.A. Cell biology in neuroscience: Death of developing neurons: New insights and implications for connectivity. J. Cell Biol. 2013, 203, 385-393. [CrossRef] [PubMed]

84. Mukherjee, A.; Williams, D.W. More alive than dead: Non-apoptotic roles for caspases in neuronal development, plasticity and disease. Cell Death Differ. 2017, 24, 1411-1421. [CrossRef] [PubMed]

85. Garcia-Fuster, M.J.; Garcia-Sevilla, J.A. Monoamine receptor agonists, acting preferentially at presynaptic autoreceptors and heteroreceptors, downregulate the cell fate adaptor FADD in rat brain cortex. Neuropharmacology 2015, 89, 204-214. [CrossRef] [PubMed] 
86. Garcia-Fuster, M.J.; Diez-Alarcia, R.; Ferrer-Alcon, M.; La Harpe, R.; Meana, J.J.; Garcia-Sevilla, J.A. FADD adaptor and PEA-15/ERK1/2 partners in major depression and schizophrenia postmortem brains: Basal contents and effects of psychotropic treatments. Neuroscience 2014, 277, 541-551. [CrossRef] [PubMed]

87. Mengying, Z.; Yiyue, X.; Tong, P.; Yue, H.; Limpanont, Y.; Ping, H.; Okanurak, K.; Yanqi, W.; Dekumyoy, P.; Hongli, Z.; et al. Apoptosis and necroptosis of mouse hippocampal and parenchymal astrocytes, microglia and neurons caused by Angiostrongylus cantonensis infection. Parasites Vectors 2017, $10,611$. [CrossRef] [PubMed]

88. Kole, A.J.; Annis, R.P.; Deshmukh, M. Mature neurons: Equipped for survival. Cell Death Dis. 2013, 4, e689. [CrossRef] [PubMed]

89. Maes, M.E.; Schlamp, C.L.; Nickells, R.W. BAX to basics: How the BCL2 gene family controls the death of retinal ganglion cells. Prog. Retin. Eye Res. 2017, 57, 1-25. [CrossRef] [PubMed]

90. Jazvinscak Jembrek, M.; Hof, P.R.; Simic, G. Ceramides in Alzheimer's Disease: Key Mediators of Neuronal Apoptosis Induced by Oxidative Stress and Abeta Accumulation. Oxid. Med. Cell. Longev. 2015, 2015, 346783. [CrossRef] [PubMed]

91. Aouacheria, A.; Baghdiguian, S.; Lamb, H.M.; Huska, J.D.; Pineda, F.J.; Hardwick, J.M. Connecting mitochondrial dynamics and life-or-death events via Bcl-2 family proteins. Neurochem. Int. 2017, 109, 141-161. [CrossRef] [PubMed]

92. Liu, J.; Liu, W.; Lu, Y.; Tian, H.; Duan, C.; Lu, L.; Gao, G.; Wu, X.; Wang, X.; Yang, H. Piperlongumine restores the balance of autophagy and apoptosis by increasing BCL2 phosphorylation in rotenone-induced Parkinson disease models. Autophagy 2018, 1-17. [CrossRef] [PubMed]

93. Samhan-Arias, A.K.; Fortalezas, S.; Cordas, C.M.; Moura, I.; Moura, J.J.G.; Gutierrez-Merino, C. Cytochrome b5 reductase is the component from neuronal synaptic plasma membrane vesicles that generates superoxide anion upon stimulation by cytochrome c. Redox Biol. 2018, 15, 109-114. [CrossRef] [PubMed]

94. Geden, M.J.; Deshmukh, M. Axon degeneration: Context defines distinct pathways. Curr. Opin. Neurobiol. 2016, 39, 108-115. [CrossRef] [PubMed]

95. Zuo, H.; Lin, T.; Wang, D.; Peng, R.; Wang, S.; Gao, Y.; Xu, X.; Li, Y.; Wang, S.; Zhao, L.; et al. Neural cell apoptosis induced by microwave exposure through mitochondria-dependent caspase-3 pathway. Int. J. Med. Sci. 2014, 11, 426-435. [CrossRef] [PubMed]

96. Zheng, V.Z.; Wong, G.K.C. Neuroinflammation responses after subarachnoid hemorrhage: A review. J. Clin. Neurosci. 2017, 42, 7-11. [CrossRef] [PubMed]

97. Stonesifer, C.; Corey, S.; Ghanekar, S.; Diamandis, Z.; Acosta, S.A.; Borlongan, C.V. Stem cell therapy for abrogating stroke-induced neuroinflammation and relevant secondary cell death mechanisms. Prog. Neurobiol. 2017, 158, 94-131. [CrossRef] [PubMed]

98. Ziemka-Nalecz, M.; Jaworska, J.; Zalewska, T. Insights Into the Neuroinflammatory Responses After Neonatal Hypoxia-Ischemia. Med. Gas Res. 2017, 76, 644-654. [CrossRef] [PubMed]

99. Chen, Z.Q.; Mou, R.T.; Feng, D.X.; Wang, Z.; Chen, G. The role of nitric oxide in stroke. Med. Gas Res. 2017, 7, 194-203. [CrossRef] [PubMed]

100. Rosenberg, G.A. Extracellular matrix inflammation in vascular cognitive impairment and dementia. Clin. Sci. 2017, 131, 425-437. [CrossRef] [PubMed]

101. Rahimifard, M.; Maqbool, F.; Moeini-Nodeh, S.; Niaz, K.; Abdollahi, M.; Braidy, N.; Nabavi, S.M.; Nabavi, S.F. Targeting the TLR4 signaling pathway by polyphenols: A novel therapeutic strategy for neuroinflammation. Ageing Res. Rev. 2017, 36, 11-19. [CrossRef] [PubMed]

102. Wang, P.F.; Xiong, X.Y.; Chen, J.; Wang, Y.C.; Duan, W.; Yang, Q.W. Function and mechanism of toll-like receptors in cerebral ischemic tolerance: From preconditioning to treatment. J. NeuroInflamm. 2015, 12, 80. [CrossRef] [PubMed]

103. Kollias, G.; Kontoyiannis, D. Role of TNF/TNFR in autoimmunity: Specific TNF receptor blockade may be advantageous to anti-TNF treatments. Cytokine Growth Factor Rev. 2002, 13, 315-321. [CrossRef]

104. Tortarolo, M.; Lo Coco, D.; Veglianese, P.; Vallarola, A.; Giordana, M.T.; Marcon, G.; Beghi, E.; Poloni, M.; Strong, M.J.; Iyer, A.M.; et al. Amyotrophic Lateral Sclerosis, a Multisystem Pathology: Insights into the Role of TNFalpha. Med. Inflamm. 2017, 2017, 2985051. [CrossRef] [PubMed]

105. Snow, W.M.; Albensi, B.C. Neuronal Gene Targets of NF-kappaB and Their Dysregulation in Alzheimer's Disease. Front. Mol. Neurosci. 2016, 9, 118. [CrossRef] [PubMed] 
106. He, Q.; Wang, Y.; Lin, W.; Zhang, Q.; Zhao, J.; Liu, F.T.; Tang, Y.L.; Xiao, B.G.; Wang, J. Trehalose alleviates PC12 neuronal death mediated by lipopolysaccharide-stimulated BV-2 cells via inhibiting nuclear transcription factor NF-kappaB and AP-1 activation. Neurotox. Res. 2014, 26, 430-439. [CrossRef] [PubMed]

107. Hong, H.; Jang, B.C. Prednisone inhibits the IL-1beta-induced expression of COX-2 in HEI-OC1 murine auditory cells through the inhibition of ERK-1/2, JNK-1 and AP-1 activity. Int. J. Mol. Med. 2014, 34, 1640-1646. [CrossRef] [PubMed]

108. Wei, J.; Du, K.; Cai, Q.; Ma, L.; Jiao, Z.; Tan, J.; Xu, Z.; Li, J.; Luo, W.; Chen, J.; et al. Lead induces COX-2 expression in glial cells in a NFAT-dependent, AP-1/NFkappaB-independent manner. Toxicology 2014, 325, 67-73. [CrossRef] [PubMed]

109. Zhang, Y.; Gao, L.; Cheng, Z.; Cai, J.; Niu, Y.; Meng, W.; Zhao, Q. Kukoamine A Prevents Radiation-Induced Neuroinflammation and Preserves Hippocampal Neurogenesis in Rats by Inhibiting Activation of NF-kappaB and AP-1. Neurotox. Res. 2017, 31, 259-268. [CrossRef] [PubMed]

110. Borrow, A.P.; Stranahan, A.M.; Suchecki, D.; Yunes, R. Neuroendocrine Regulation of Anxiety: Beyond the Hypothalamic-Pituitary-Adrenal Axis. J. Neuroendocrinol. 2016, 28. [CrossRef] [PubMed]

111. Muller, C.P.; Reichel, M.; Muhle, C.; Rhein, C.; Gulbins, E.; Kornhuber, J. Brain membrane lipids in major depression and anxiety disorders. Biochim. Biophys. Acta 2015, 1851, 1052-1065. [CrossRef] [PubMed]

112. Ohno, Y.; Shimizu, S.; Tokudome, K.; Kunisawa, N.; Sasa, M. New insight into the therapeutic role of the serotonergic system in Parkinson's disease. Prog. Neurobiol. 2015, 134, 104-121. [CrossRef] [PubMed]

113. Mifflin, K.; Benson, C.; Kerr, B.; Aricioglu, F.; Cetin, M.; Dursun, S.; Baker, G. Involvement of Neuroactive Steroids in Pain, Depression and Anxiety. Mod. Trends Pharmacopsychiatr. 2015, 30, 94-102. [CrossRef]

114. Koubaa, M.; Barba, F.J.; Greiner, R.; Johnson, S.K.; Strawn, J.R.; Dobson, E.T.; Giles, L.L. Primary Pediatric Care Psychopharmacology: Focus on Medications for ADHD, Depression, and Anxiety. J. Sci. Food Agric. 2017, 47, 3-14. [CrossRef]

115. Wiebking, C.; Duncan, N.W.; Tiret, B.; Hayes, D.J.; Marjanska, M.; Doyon, J.; Bajbouj, M.; Northoff, G. GABA in the insula-A predictor of the neural response to interoceptive awareness. Neuroimage 2014, 86, 10-18. [CrossRef] [PubMed]

116. Miller, A.H.; Haroon, E.; Raison, C.L.; Felger, J.C. Cytokine targets in the brain: Impact on neurotransmitters and neurocircuits. Depress. Anxiety 2013, 30, 297-306. [CrossRef] [PubMed]

117. Schatzberg, A.F. Development of New Psychopharmacological Agents for Depression and Anxiety. Psychiatr. Clin. N. Am. 2015, 38, 379-393. [CrossRef] [PubMed]

118. Dincheva, I.; Lynch, N.B.; Lee, F.S. The Role of BDNF in the Development of Fear Learning. Depress Anxiety. 2016, 33, 907-916. [CrossRef] [PubMed]

119. Murck, H. Ketamine, magnesium and major depression-From pharmacology to pathophysiology and back. J. Psychiatr. Res. 2013, 47, 955-965. [CrossRef] [PubMed]

120. Mendez-David, I.; Hen, R.; Gardier, A.M.; David, D.J. Adult hippocampal neurogenesis: An actor in the antidepressant-like action. Ann. Pharm. Fr. 2013, 71, 143-149. [CrossRef] [PubMed]

121. Rogers, J.; Renoir, T.; Hannan, A.J. Gene-environment interactions informing therapeutic approaches to cognitive and affective disorders. Neuropharmacology 2017. [CrossRef] [PubMed]

122. Silverstein, W.K.; Noda, Y.; Barr, M.S.; Vila-Rodriguez, F.; Rajji, T.K.; Fitzgerald, P.B.; Downar, J.; Mulsant, B.H.; Vigod, S.; Daskalakis, Z.J.; et al. Neurobiological predictors of response to dorsolateral prefrontal cortex repetitive transcranial magnetic stimulation in depression: A systematic review. Depress. Anxiety 2015, 32, 871-891. [CrossRef] [PubMed]

123. Vasconcelos, M.; Stein, D.J.; de Almeida, R.M. Social defeat protocol and relevant biomarkers, implications for stress response physiology, drug abuse, mood disorders and individual stress vulnerability: A systematic review of the last decade. Trends Psychiatry Psychother. 2015, 37, 51-66. [CrossRef] [PubMed]

124. Morrison, F.G.; Ressler, K.J. From the neurobiology of extinction to improved clinical treatments. Depress. Anxiety 2014, 31, 279-290. [CrossRef] [PubMed]

125. Yalcin, I.; Barthas, F; Barrot, M. Emotional consequences of neuropathic pain: Insight from preclinical studies. Neurosci. Biobehav. Rev. 2014, 47, 154-164. [CrossRef] [PubMed]

126. Hu, D.; Han, N.; Yao, X.; Liu, Z.; Wang, Y.; Yang, J.; Yin, J. Structure-activity relationship study of dibenzocyclooctadiene lignans isolated from Schisandra chinensis on lipopolysaccharide-induced microglia activation. Planta Med. 2014, 80, 671-675. [CrossRef] [PubMed] 
127. Wang, M.C.; Lai, Y.C.; Chang, C.L. High throughput screening and antioxidant assay of dibenzo[a,c]cyclooctadiene lignans in modified-ultrasonic and supercritical fluid extracts of Schisandra chinensis Baill by liquid chromatography-Mass spectrometry and a free radical-scavenging method. J. Sep. Sci. 2008, 31, 1322-1332. [CrossRef] [PubMed]

128. Hayakawa, K.; Esposito, E.; Wang, X.; Terasaki, Y.; Liu, Y.; Xing, C.; Ji, X.; Lo, E.H. Transfer of mitochondria from astrocytes to neurons after stroke. Nature 2016, 535, 551-555. [CrossRef] [PubMed]

129. Morizawa, Y.M.; Hirayama, Y.; Ohno, N.; Shibata, S.; Shigetomi, E.; Sui, Y.; Nabekura, J.; Sato, K.; Okajima, F.; Takebayashi, H.; et al. Reactive astrocytes function as phagocytes after brain ischemia via ABCA1-mediated pathway. Nat. Commun. 2017, 8, 28. [CrossRef] [PubMed]

130. Delekate, A.; Fuchtemeier, M.; Schumacher, T.; Ulbrich, C.; Foddis, M.; Petzold, G.C. Metabotropic P2Y1 receptor signalling mediates astrocytic hyperactivity in vivo in an Alzheimer's disease mouse model. Nat. Commun. 2014, 5, 5422. [CrossRef] [PubMed]

131. Shi, Y. Rapid endothelial cytoskeletal reorganization enables early blood-brain barrier disruption and long-term ischaemic reperfusion brain injury. Nat. Commun. 2016, 7, 10523. [CrossRef] [PubMed]

132. Tang, A.T.; Choi, J.P.; Kotzin, J.J.; Yang, Y.; Hong, C.C.; Hobson, N.; Girard, R.; Zeineddine, H.A.; Lightle, R.; Moore, T.; et al. Endothelial TLR4 and the microbiome drive cerebral cavernous malformations. Nature 2017, 545, 305-310. [CrossRef] [PubMed]

133. Fisher, O.S.; Deng, H.; Liu, D.; Zhang, Y.; Wei, R.; Deng, Y.; Zhang, F.; Louvi, A.; Turk, B.E.; Boggon, T.J.; et al. Structure and vascular function of MEKK3-cerebral cavernous malformations 2 complex. Nat. Commun. 2015, 6, 7937. [CrossRef] [PubMed]

134. Hamilton, N.B.; Kolodziejczyk, K.; Kougioumtzidou, E.; Attwell, D. Proton-gated Ca( $\left.{ }^{2+}\right)$-permeable TRP channels damage myelin in conditions mimicking ischaemia. Nature 2016, 529, 523-527. [CrossRef] [PubMed]

135. Zhao, X.; Ting, S.M.; Liu, C.H.; Sun, G.; Kruzel, M.; Roy-O’Reilly, M.; Aronowski, J. Neutrophil polarization by IL-27 as a therapeutic target for intracerebral hemorrhage. Nat. Commun. 2017, 8, 602. [CrossRef] [PubMed]

136. Koh, H.S.; Chang, C.Y.; Jeon, S.B.; Yoon, H.J.; Ahn, Y.H.; Kim, H.S.; Kim, I.H.; Jeon, S.H.; Johnson, R.S.; Park, E.J. The HIF-1/glial TIM-3 axis controls inflammation-associated brain damage under hypoxia. Nat. Commun. 2015, 6, 6340. [CrossRef] [PubMed]

137. Bi, M.; Gladbach, A.; van Eersel, J.; Ittner, A.; Przybyla, M.; van Hummel, A.; Chua, S.W.; van der Hoven, J.; Lee, W.S.; Muller, J. Tau exacerbates excitotoxic brain damage in an animal model of stroke. Nat. Commun. 2017, 8, 473. [CrossRef] [PubMed]

138. Yan, H.; Zhang, X.; Hu, W.; Ma, J.; Hou, W.; Zhang, X.; Wang, X.; Gao, J.; Shen, Y.; Lv, J.; et al. Histamine H3 receptors aggravate cerebral ischaemic injury by histamine-independent mechanisms. Nat. Commun. 2014, 5, 3334. [CrossRef] [PubMed]

(c) 2018 by the authors. Licensee MDPI, Basel, Switzerland. This article is an open access article distributed under the terms and conditions of the Creative Commons Attribution (CC BY) license (http://creativecommons.org/licenses/by/4.0/). 